\title{
Integration of liquid biopsy and pharmacogenomics for precision therapy of EGFR mutant and resistant lung cancers
}

\author{
Jill Kolesar', Spencer Peh', Levin Thomas², Gayathri Baburaj², Nayonika Mukherjee², Raveena Kantamneni², \\ Shirley Lewis ${ }^{3}$, Ananth Pai ${ }^{4}$, Karthik S. Udupa ${ }^{4}$, Naveena Kumar AN ${ }^{5}$, Vivek M. Rangnekar ${ }^{6}$ and Mahadev Rao ${ }^{2^{*}}$ (D
}

\begin{abstract}
The advent of molecular profiling has revolutionized the treatment of lung cancer by comprehensively delineating the genomic landscape of the epidermal growth factor receptor (EGFR) gene. Drug resistance caused by EGFR mutations and genetic polymorphisms of drug metabolizing enzymes and transporters impedes effective treatment of EGFR mutant and resistant lung cancer. This review appraises current literature, opportunities, and challenges associated with liquid biopsy and pharmacogenomic (PGX) testing as precision therapy tools in the management of EGFR mutant and resistant lung cancers. Liquid biopsy could play a potential role in selection of precise tyrosine kinase inhibitor (TKI) therapies during different phases of lung cancer treatment. This selection will be based on the driver EGFR mutational status, as well as monitoring the development of potential EGFR mutations arising during or after TKls treatment, since some of these new mutations may be druggable targets for alternative TKIs. Several studies have identified the utility of liquid biopsy in the identification of EGFR driver and acquired resistance with good sensitivities for various blood-based biomarkers. With a plethora of sequencing technologies and platforms available currently, further evaluations using randomized controlled trials (RCTs) in multicentric, multiethnic and larger patient cohorts could enable optimization of liquid-based assays for the detection of EGFR mutations, and support testing of CYP450 enzymes and drug transporter polymorphisms to guide precise dosing of EGFRTKIs.
\end{abstract}

Keywords: EGFR, Liquid biopsy, Lung cancer, Pharmacogenomics, Precision therapy, Tyrosine kinase inhibitors

\section{Introduction}

More than 19.3 million new cases of cancer were reported worldwide in 2020. Globally, lung cancer is the leading cancer that accounts for $11.4 \%$ of all cases and is also the leading cause of cancer related deaths [1]. Over the previous 20 years, a focus on genomics research has led to the identification of genomic drivers of lung cancer. The first identified and most broadly studied is epidermal growth factor receptor (EGFR), a transmembrane

\footnotetext{
*Correspondence: mahadev.rao@manipal.edu

${ }^{2}$ Department of Pharmacy Practice, Manipal College of Pharmaceutical

Sciences, Manipal Academy of Higher Education, Manipal, Karnataka 576104, India

Full list of author information is available at the end of the article
}

receptor tyrosine kinase that is part of the ErbB family. EGFR activating mutations act to amplify downstream phosphorylation cascade signaling, resulting in increased cell proliferation and survival. Activating EGFR mutations are the known drivers of lung cancer that accounts for approximately 10 to $15 \%$ of non-small cell lung cancer (NSCLC) diagnoses [2-5] and assessment of EGFR mutations is now routinely performed as standard of care.

Tissue biopsy is the gold standard for selecting targeted therapies for NSCLC and current guidelines recommend liquid biopsies to guide initial therapeutic decisions in advanced NSCLC only if obtaining a tissue biopsy is not feasible [6-8]. However, when compared to tissue biopsies, liquid biopsies are less invasive, do not rely on original author(s) and the source, provide a link to the Creative Commons licence, and indicate if changes were made. The images or other third party material in this article are included in the article's Creative Commons licence, unless indicated otherwise in a credit line to the material. If material is not included in the article's Creative Commons licence and your intended use is not permitted by statutory regulation or exceeds the permitted use, you will need to obtain permission directly from the copyright holder. To view a copy of this licence, visit http://creativecommons.org/licenses/by/4.0/. The Creative Commons Public Domain Dedication waiver (http://creativeco mmons.org/publicdomain/zero/1.0/) applies to the data made available in this article, unless otherwise stated in a credit line to the data. 
obtaining a tissue biopsy, reduce procedural complications, and importantly can serve as a tool for monitoring EGFR treatment resistance and efficacy. Serial liquid biopsy monitoring throughout a patient's treatment can allow researchers to identify and understand genomic resistance mechanisms [9-13].

Many liquid biopsies in development are blood-based but testing methods are highly variable. Metastases from a primary tumor requires multiple biological processes that include invasion into the vascular circulation, seeding in distant tissue, and forming a vascular network necessary for cellular survival and proliferation [14]. Blood-based liquid biopsies exploit these tumor characteristics to detect cellular components or genomic contents released by cancer cells into the peripheral blood $[14,15]$. Next generation sequencing (NGS) technology has allowed improved detection of cell free DNA (cfDNA) or circulating tumor DNA (ctDNA) and are the only clinically validated methods as companion diagnostics for EGFR mutated NSCLC [16, 17]. Several other blood-based liquid biopsies in development include circulating tumor cells (CTCs), microRNA (miRNA), long non-coding RNA (lncRNA), exosomes, and tumor-educated platelets (TEPs) that have the potential for diagnostics, prognostics, and predicting treatment resistance in EGFR mutated lung cancer [18-26]. Liquid biopsies of pleural effusion fluid are another promising method that is currently being investigated to potentially overcome the limitations of peripheral blood liquid biopsies [27].

An often-overlooked aspect of precision therapy is pharmacogenetic (PGx) variations in drug metabolism. Approximately $80 \%$ of drugs available in the United States are metabolized via the cytochrome 450 (CYP450) pathway, including the majority of EGFR TKIs $[28,29]$. CYP450 is a family of enzymes involved in oxidation or conjugation of xenobiotics, rendering drugs more hydrophilic and eventually allowing for renal excretion $[29,30]$. In addition, multi-drug resistant transporter proteins (MDRPs) such as permeability glycoprotein (P-gp) or breast cancer resistant protein (BCRP) influence xenobiotic transport [31]. P-gP and BCRP are ATPbinding cassette proteins and act as efflux transporters of xenobiotics, including some EGFR inhibitors [32]. Single nucleotide polymorphisms (SNPs) in CYP450s and MDRPs cause variations in pharmacokinetic (PK) and pharmacodynamic (PD) properties of drugs across disease states including cancer [29, 30]. Germline PGx variations in CYP450s and MDRPs can impact the PK/ PD properties of EGFR TKIs and subsequently result in increased toxicity or decreased efficacy in certain subsets of the patient population. Pre-emptive testing of germline PGx is not yet standard of care in oncology. With the increasing use of liquid biopsies in clinical practice, there are opportunities to incorporate germline PGx testing given other incidental findings of germline mutations in patients [33]. Such an integrated approach of liquid biopsy and PGx testing could pave the way for precision therapy in lung cancer by tumor detection, dynamic monitoring of EGFR mutations and acquired resistance, as well as aid in the selection of precise drug therapy via serial molecular profiling from blood as shown in Fig. 1.

The purpose of this review is to summarize current literature, opportunities, and challenges for liquid biopsy and PGx testing as precision therapy tools in the management of EGFR mutated lung cancer.

\section{EGFR TKIs therapy and resistance}

The EGFR gene encodes a transmembrane protein having 1186 amino acids, with the extracellular region/ ectodomain accounting for 621 residues [34]. The EGFR gene comprises 28 exons, with the exons 18-21 coding for ATP-binding within the tyrosine kinase domain [35]. Human EGFR is a transmembrane glycoprotein with a glycosylated extracellular domain that binds peptide growth factor ligands, a single transmembrane region, and a cytoplasmic domain with tyrosine kinase activity that plays a key role in the regulation of cellular proliferation, differentiation, survival, and metastasis [36-39]. Actionable driver mutations detected in patients with advanced NSCLC are sensitizing EGFR mutations, which affect about $50 \%$ of Asians and 15\% of Caucasians [40, 41]. Exon 19 deletions and exon 21 L858R point mutations are the most prevalent EGFR sensitizing mutations, accounting for approximately $90 \%$ of mutations in NSCLC and leading to high sensitivity to TKIs [40, 42-46].

Traditionally, platinum-based chemotherapy was the first-line therapy for advanced non-small cell lung cancer (NSCLC). Regardless of clinical characteristics, guidelines recommend that all advanced lung adenocarcinoma patients should be tested for EGFR mutations [47, 48]. Lung adenocarcinoma patients should be assessed for oncogenic drivers and treated with targeted therapy [49] if targetable mutations are present. EGFR TKIs are suggested as the primary therapy for EGFR-mutant patients by the European Society for Medical Oncology (ESMO) [47], American Society of Clinical Oncology (ASCO) [50], and the National Comprehensive Cancer Network (NCCN) [51]. In patients with an EGFR mutation, EGFR TKIs considerably improved clinical outcomes, such as progression-free survival (PFS) and overall response rate (ORR). Patients with lung adenocarcinoma and EGFR mutation have a response rate of up to $81.6 \%$ and a PFS of approximately 9.7 to 13.3 months [43]. For metastatic NSCLC patients with EGFR mutations, several phase III clinical trials have found that first-generation and 


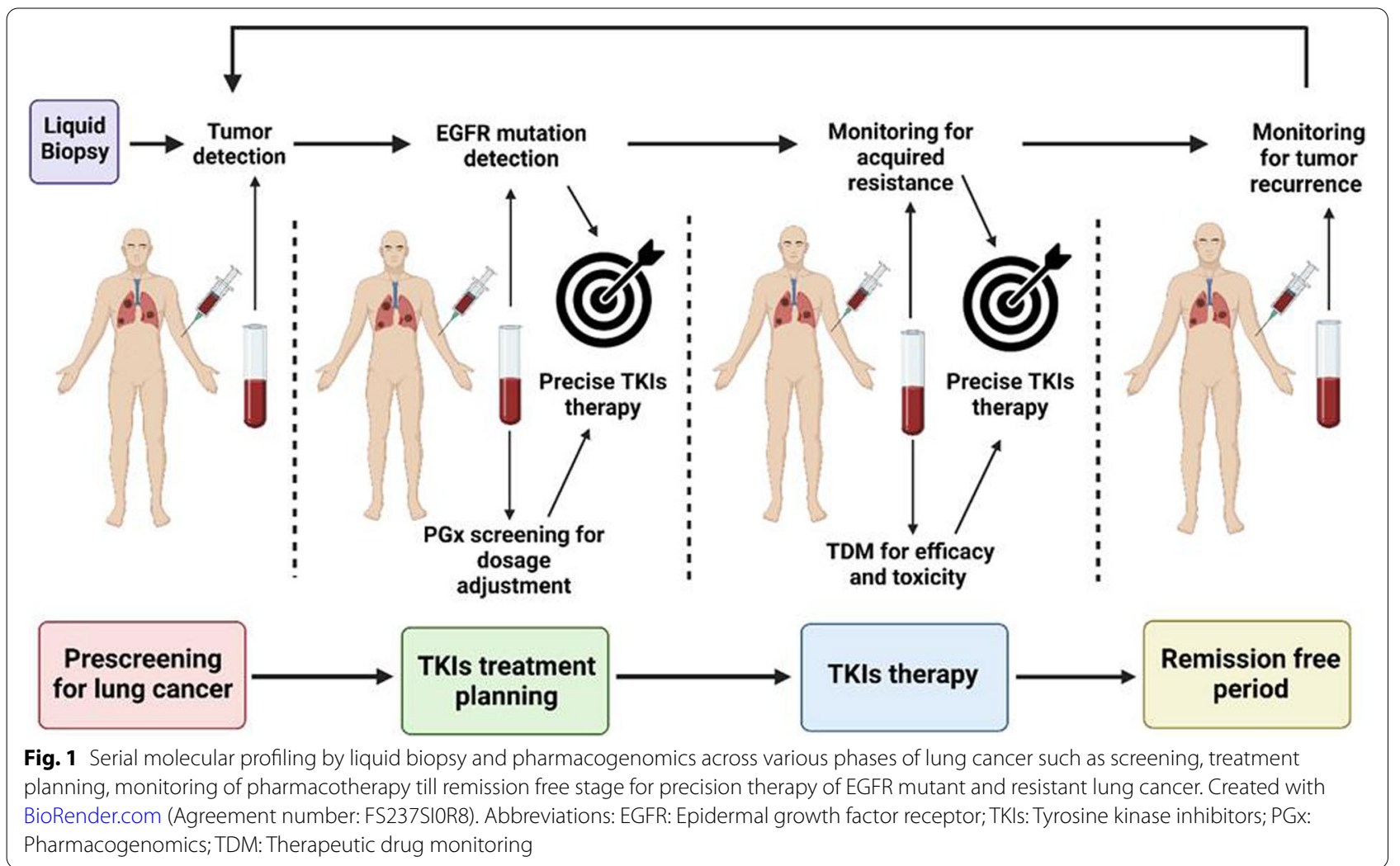

second-generation TKIs are more efficacious than firstline platinum-based chemotherapy [52]. Although most patients with an EGFR mutation are likely to benefit from EGFR TKIs, many develop progressive disease within a year of initiating therapy [53]. Furthermore, long-term efficacy of EGFR TKIs is reduced by acquired resistance.

\section{History of EGFR TKIs development}

The first EGFR inhibitor, gefitinib, was initially approved for the treatment of NSCLC regardless of mutation status based on phase II data, which did not translate to improved outcomes in large phase III trials and led to the withdrawal of gefitinib from the US market unless patients were receiving the drug and benefiting [54]. Around that time, reports emerged regarding the importance of EGFR mutations in predicting response to EGFR inhibitors [55-57]. Subsequent studies of the first-generation EGFR TKIs enrolled patients based on EGFR mutation status and compared outcomes to front line chemotherapy. Gefitinib and erlotinib demonstrated improved PFS in comparison to chemotherapy and were approved as first-line therapy for individuals with EGFRmutated NSCLC. However, overall survival (OS) was similar, suggesting development of resistance or high rates of cross-over from the chemotherapy arms after trial completion [44, 58-60].
After approvals in the front-line setting, subsequent EGRF inhibitors were compared to gefitinib or erlotinib. Afatinib is another first-generation EGFR TKI which demonstrated a time to treatment failure of 13.7 versus 11.5 months when compared to gefitinib [61]. Osimertinib was assessed in trials that enrolled patients with EGFR L858R (FLAURA), exon 19 deletion (FLAURA), and T790M (AURA3). Osimertinib demonstrated significant OS benefits in the FLAURA trial [62] but not in the AURA3 trial [63]. Despite overcoming EGFR T790M mutation in NSCLC, patients will usually develop other resistance mechanisms, resulting in loss of EGFR TKIs efficacy. Therefore, there is a dire need to understand and monitor treatment resistance mechanisms for further therapy development. Aside from efficacy and resistance, another pertinent aspect of precision oncology for EGFR TKIs is the tolerability of toxicities in different patient populations.

\section{Mechanisms of acquired resistance to EGFR TKIs}

Disease progression (based on WHO criteria or RECIST) while on EGFR TKIs is often caused by EGFR resistance to the treatment. It is a major hurdle to overcome in providing the most efficacious treatment to individuals with EGFR-mutant NSCLC [64]. Usually, acquired resistance to EGFR TKIs evolves after a median of 9.2-14.7 months 
[44, 45, 59, 65]. Target gene modification, alternative pathway activation, and histological or phenotypic transformation are the three prevalent mechanisms of acquired resistance to EGFR TKIs [66] (Fig. 2).

\section{EGFR-dependent mechanism: target gene modification}

EGFR T790M mutation, which replaces methionine with threonine at position 790 in exon 20 of EGFR, is a common mechanism of resistance to EGFR TKIs. It accounts for $50-60 \%$ of the cases $[67,68]$. T790M may promote EGFR TKIs such as gefitinib, erlotinib, and afatinib resistance by generating steric hindrance to TKIs binding to the ATP-binding pocket, or by increasing EGFR's ATP binding affinity. The T790M mutation in EGFR may restore the mutant receptor's affinity for ATP, lowering the effectiveness of competitive inhibitors

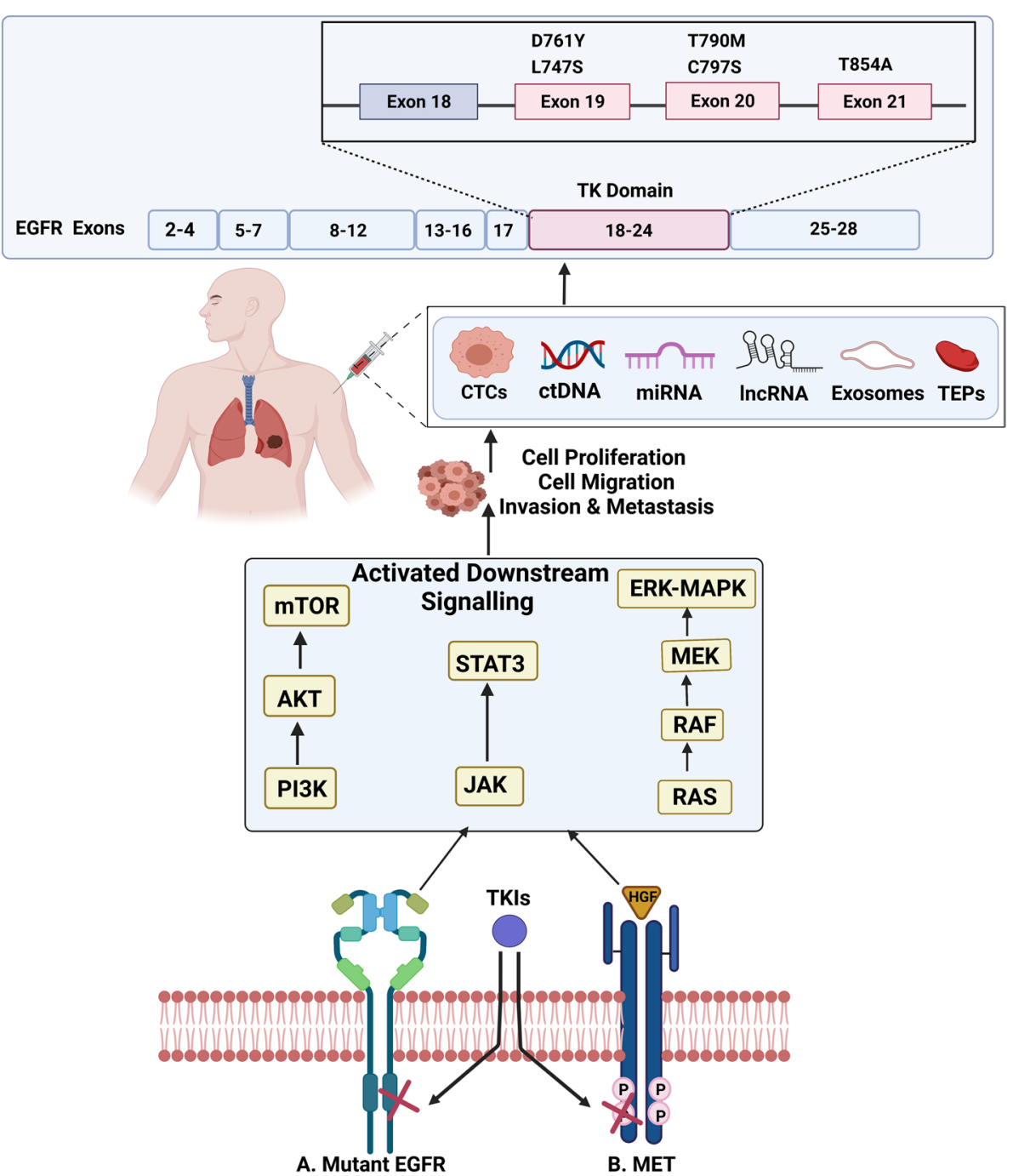

Fig. 2 Schematic diagram explaining mechanisms of acquired resistance to EGFRTKIs. A. Mutant EGFR confers resistance to binding of TKIs to the tyrosine kinase domain of EGFR. This activates downstream signaling pathways such as the PI3K-AKT pathway, JAK-STAT pathway, RAS pathway and ERK-MAPK pathway. B. Overexpression of HGF causes TKI-resistance that activates downstream signaling of the PI3K-AKT pathway, JAK-STAT pathway, RAS pathway and ERK-MAPK pathway. The above pathways result in cell proliferation, cell migration, invasion, and metastasis, that in turn cause the release of CTCS, CtDNA, miRNA, InCRNA, exosomes and TEPs into the bloodstream. Liquid biopsy helps examine these biomarkers and assess the type of mutation. Created with BioRender.com (Agreement number: XF237SHT72). Abbreviations: EGFR: Epidermal growth factor receptor; TK: Tyrosine kinase; CTCs: Circulating tumor cells; ctDNA: Circulating tumor DNA; miRNA: Micro RNA; IncRNA: Long non-coding RNA; TEPs: Tumor educated platelets; mTOR: Mammalian target of rapamycin; AKT:V-akt murine thymoma viral oncogene homolog; PI3K: Phosphoinositide 3-kinase; STAT3: Signal transducer and activator of transcription 3; JAK: Janus Activated Kinase; ERK: Extracellular-signal-regulated kinase; MAPK: Mitogen-activated protein kinase; MEK: Mitogen-activated protein kinase kinase; RAF: Rapidly Accelerated Fibrosarcoma; RAS: Rat sarcoma virus; HGF: Hepatocyte growth factor; TKIs: Tyrosine kinase inhibitors; MET: Mesenchymal epithelial transition factor 
[67, 69]. Detection of EGFR T790M status is important since it affects treatment choice indicating the use of the third-generation EGFR TKI, osimertinib as a second-line therapy [70].

\section{EGFR-independent mechanism: alternative pathway activation}

The activation of alternative or bypass pathways can also produce acquired resistance. The most prevalent bypass mechanism is MET amplification, accounting for $5-10 \%$ of patients with resistance to TKIs [66, 71, 72]. The MET gene encodes the receptor tyrosine kinase c-MET, and binding of MET to its ligand, hepatocyte growth factor (HGF), causes tyrosine phosphorylation of the receptor and initiation of downstream signaling pathways, such as phosphoinositide 3-kinase (PI3K) and V-akt murine thymoma viral oncogene homolog (AKT), signal transducer and activator of transcription 3 (STAT3), rat sarcoma virus (RAS), and mitogen-activated protein kinase (MAPK). Combination trials of MET directed therapies and T790M targeting inhibitors are important because MET amplification and T790M mutation are not mutually exclusive [73]. MET gene amplification can initiate PI3K-AKT pathway independently of EGFR by ERBB3 dimerization and signaling [72]. However, the MET amplification threshold that confers acquired resistance to TKI-therapy is yet to be determined. EGFR TKIs resistance is also promoted by overexpression of HGF, the ligand of MET oncoprotein [74]. Other alternative mechanisms that have been reported to cause resistance to TKIs, including KRAS mutation, BRAF mutation [75, 76], HER2 amplification [77], phosphatidylinositol 4,5-bisphosphate 3-kinase catalytic subunit alpha isoform (PIK3CA) mutation [78], and enhanced expression of the receptor tyrosine kinase AXL [79].

\section{Histological and phenotypic transformation}

During or after treatment with EGFR TKIs, a subset of individuals (i.e., 5-10\%) with NSCLC and EGFR mutations develops histologic transformation of adenocarcinoma into small-cell lung cancer (SCLC) [78, 80-82].

Prolonged EGFR inhibition in NSCLC can result in the appearance of SCLC-like histologic, genetic, and pharmacological sensitivity profiles. The epithelial-to-mesenchymal transition (EMT) program has also been linked to SCLC transformation, as demonstrated by decreased expression of E-cadherin and enhanced expression of vimentin [78]. EMT was reported as a mechanism of resistance to TKIs, with EMT identified in 2 of 37 (i.e., $5 \%$ ) patients in tumor specimens obtained after EGFR treatment and SCLC transformation [78]. Slug, ZEB1, Snail, and AXL are examples of EMT transcription factors that undergo alterations due to acquired resistance to TKIs [83, 84].

\section{Liquid biopsy in EGFR mutant NSCLC detection Comparative superiority over tissue biopsy-studies with results in EGFR mutant/resistant lung cancer}

Liquid biopsy efficiently analyzes CTCs, ctDNA, miRNA, lncRNA, exosomes, and TEPs [23, 25, 26, 85]. Table 1 summarizes the characteristics of the biomarkers with their corresponding isolation techniques, clinical applications, and limitations. ctDNAs formed by the DNA fragments are released into the bloodstream by cell death, especially via necrosis $[103,104]$. ctDNA can be extracted from a variety of bodily fluids, including saliva, sputum, CSF, urine, and pleural secretions, in addition to plasma $[105,106]$. Despite its moderate sensitivity, urine ctDNA is a viable alternative for detecting EGFR mutations [107]. With a concordance of $84.62 \%$ among all patients, [108] tissue biopsy and liquid biopsy using ctDNA can have distinct effects on the prognosis and treatment strategies of EGFR mutant non-small cell lung adenocarcinoma. Although ctDNA is approved for the detection of EGFR mutant in NSCLC patients, [109] adenocarcinomas are more likely to be detected by the established miRNA markers over squamous cell carcinoma [110]. A retrospective study of 308 lung cancer patients who had re-biopsy and 118 patients who had liquid biopsy, found that 134 patients $(43.5 \%)$ in the re-biopsy group and 49 patients (41.5\%) in the liquid biopsy group tested positive for EGFR T790M. The liquid biopsy's specificity and sensitivity for detecting T790M was 84.4 and $34 \%$, respectively. The study showed that $75.0 \%$ of the patients in the liquid biopsy group and $52.3 \%$ of the patients in the rebiopsy group, who tested positive for T790M mutation were likely to get treated by a third-generation TKI [10]. Sacher et al. prospectively assessed 180 patients to determine the correlation between tissue re-biopsy and liquid biopsy. The sensitivity, specificity, and positive predictive value of ctDNA based T790M detection using digital droplet polymerase chain reaction (ddPCR) was reported to be $77.1,63.2$, and $79 \%$, respectively [111].

In liquid biopsy, the plasma samples are predominantly analyzed using quantitative polymerase chain reaction (qPCR), digital PCR (dPCR) or ddPCR, and NGS [112]. Feng Li et al. compared the concordance of electric field-induced release and measurement (EFIRM)-based liquid biopsy with ddPCR to establish the superiority of the former. The study concluded a $100 \%$ sensitivity for EFIRM as opposed to $84.6 \%$ sensitivity in the detection of EGFR mutation in plasma samples. This is because of the limitation of PCR to amplify short DNA fragments (shorter than $70 \mathrm{bps}$ ) [113]. The largest prospective, multicenter trial on cfDNA 
Table 1 The characteristics of the biomarkers with their corresponding isolation techniques, clinical applications and limitations

\begin{tabular}{|c|c|c|c|c|}
\hline Biomarkers & Isolation technique & Clinical application & Limitations & References \\
\hline \multirow[t]{8}{*}{ Circulating tumor cells (CTCs) } & Immunomagnetic enrichment & $\begin{array}{l}\text { - Prognosis } \\
\text { - Treatment }\end{array}$ & $\begin{array}{l}\text { - Reproducibility } \\
\text { - Sensitivity } \\
\text { - CTC without epithelial marker } \\
\text { could not be detected } \\
\text { - Difficult to use with whole } \\
\text { blood } \\
\text { - Low purity of detected CTC } \\
\text { - Cannot process whole blood } \\
\text { - High detection cost }\end{array}$ & {$[86]$} \\
\hline & Immunomagnetic isolation & $\begin{array}{l}\text { - Diagnosis } \\
\text { - Prognosis }\end{array}$ & $\begin{array}{l}\text { - Reliance on EpCAM and CK } \\
\text { - Variation of expression of } \\
\text { EpCAM and CK across cancers } \\
\text { - Lack of selectivity } \\
\text { - High detection cost }\end{array}$ & {$[87]$} \\
\hline & Magnetic beads & $\begin{array}{l}\text { - Prognosis } \\
\text { - Treatment }\end{array}$ & $\begin{array}{l}\text { - Increased contamination with } \\
\text { WBC } \\
\text { - Requires more blood }\end{array}$ & {$[88]$} \\
\hline & $\begin{array}{l}\text { Microfluidic positive immuno- } \\
\text { capture } \\
\text { (CTC-chip) }\end{array}$ & $\begin{array}{l}\text { - Prognosis } \\
\text { - Diagnosis }\end{array}$ & $\begin{array}{l}\text { - Shear force might affect cell } \\
\text { viability and attachment } \\
\text { - Slow rate processing } \\
\text { - Limited volume }\end{array}$ & [89] \\
\hline & $\begin{array}{l}\text { Size based separation } \\
\text { (filter-based isolation) }\end{array}$ & $\begin{array}{l}\text { - Prognosis } \\
\text { - Treatment }\end{array}$ & $\begin{array}{l}\text { - Prone to clogging } \\
\text { - Requires high volume of blood } \\
\text { - Sample may be adulterated }\end{array}$ & [90] \\
\hline & Density gradient separation & $\begin{array}{l}\text { - Prognosis } \\
\text { - Treatment }\end{array}$ & $\begin{array}{l}\text { - Loss of large CTC and cell } \\
\text { aggregates } \\
\text { - Low purity }\end{array}$ & [91] \\
\hline & Inertial focusing & $\begin{array}{l}\text { - Prognosis } \\
\text { - Diagnosis } \\
\text { - Treatment }\end{array}$ & $\begin{array}{l}\text { - Morphological deformation of } \\
\text { the captured cell }\end{array}$ & [92] \\
\hline & Single cell sequencing & $\begin{array}{l}\text { - Prognosis } \\
\text { - Treatment }\end{array}$ & $\begin{array}{l}\text { - Poor reproducibility } \\
\text { - False positives and false nega- } \\
\text { tives } \\
\text { - Allele deletion } \\
\text { - Sequencing errors }\end{array}$ & [93] \\
\hline Circulating tumor DNA (ctDNA) & $\begin{array}{l}\text { Manual (DNA purification) } \\
\text { Automated (ccfDNA purification) }\end{array}$ & $\begin{array}{l}\text { - Detection } \\
\text { - Prognosis } \\
\text { - Treatment initiation and } \\
\text { monitoring }\end{array}$ & $\begin{array}{l}\text { - Low accuracy and precision } \\
\text { - Requires adequate control for } \\
\text { downstream application } \\
\text { - Only for use with plasma pre- } \\
\text { pared from human whole blood } \\
\text { samples collected in EDTA tube } \\
\text { - Not for use in diagnostic } \\
\text { procedures }\end{array}$ & [94] \\
\hline
\end{tabular}


Table 1 (continued)

\begin{tabular}{|c|c|c|c|c|}
\hline Biomarkers & Isolation technique & Clinical application & Limitations & References \\
\hline \multirow[t]{4}{*}{ ctRNA (miRNA, IncRNA) } & Northern blot analysis & - Diagnosis & $\begin{array}{l}\text { - mRNA degradation during } \\
\text { electrophoresis } \\
\text { - Low sensitivity } \\
\text { - Detection with multiple } \\
\text { probes is difficult }\end{array}$ & {$[95]$} \\
\hline & Microarray & $\begin{array}{l}\text { - Diagnosis } \\
\text { - Therapeutic response predic- } \\
\text { tion }\end{array}$ & $\begin{array}{l}\text { - Standardization and optimiza- } \\
\text { tion } \\
\text { - Low specificity } \\
\text { - Low reproducibility } \\
\text { - High cost of a single experi- } \\
\text { ment } \\
\text { - Unsuitable for clinical experi- } \\
\text { ences }\end{array}$ & {$[96]$} \\
\hline & RT-qPCR & $\begin{array}{l}\text { - Diagnosis } \\
\text { - Treatment initiation and } \\
\text { monitoring }\end{array}$ & $\begin{array}{l}\text { - Amplification bias } \\
\text { - No template controls } \\
\text { - Cannot perform multiple } \\
\text { detection }\end{array}$ & {$[97]$} \\
\hline & Liquid chip technology & $\begin{array}{l}\text { - Diagnosis } \\
\text { - Prognosis } \\
\text { - Treatment } \\
\text { - Resistance monitoring }\end{array}$ & $\begin{array}{l}\text { - In vivo validation } \\
\text { - Difficult to scale up }\end{array}$ & {$[88]$} \\
\hline \multirow[t]{4}{*}{ Exosomes } & Ultracentrifugation-based & $\begin{array}{l}\text { - Early diagnosis } \\
\text { - Prognosis }\end{array}$ & $\begin{array}{l}\text { - Contamination and exosome } \\
\text { loss } \\
\text { - Low recovery } \\
\text { - Laborious }\end{array}$ & {$[98]$} \\
\hline & Size-based & - Diagnosis & $\begin{array}{l}\text { - Deformation of EVs } \\
\text { - High risk of chip clogging } \\
\text { - Long run time }\end{array}$ & [99] \\
\hline & Immunoaffinity capture-based & - Diagnosis & $\begin{array}{l}\text { - Antibody cross reactivity } \\
\text { - Possible detection of non-EV } \\
\text { particles } \\
\text { - Only exosomes with targeted } \\
\text { proteins can be separated } \\
\text { - Low yield } \\
\text { - Tumor heterogeneity hinders } \\
\text { immune recognition } \\
\text { - Time consuming } \\
\text { - Expensive }\end{array}$ & {$[98]$} \\
\hline & Microfluidics based & - Diagnosis & $\begin{array}{l}\text { - Lack of standardization and } \\
\text { method validation } \\
\text { - Moderate to low sample } \\
\text { capacity }\end{array}$ & {$[100]$} \\
\hline Tumor-educated platelets (TEPs) & Spliced TEP mRNA & $\begin{array}{l}\text { - Diagnosis } \\
\text { - Treatment monitoring }\end{array}$ & $\begin{array}{l}\text { - Complex isolation technique } \\
\text { - Fragility of TEPs }\end{array}$ & {$[101,102]$} \\
\hline
\end{tabular}

Abbreviations: CTCS Circulating Tumor Cells, EpCAM Epithelial cell adhesion molecule, CK Cytokeratin, WBC White blood cell, ctDNA Circulating tumor DNA, ccfDNA Circulating cell free DNA, EDTA Ethylenediamine tetraacetic acid, ctRNA Circulating tumor RNA, miRNA MicroRNA, IncRNA Long non-coding RNA, mRNA Messenger RNA, $R T-q P C R$ Quantitative real-time polymerase chain reaction, EVs Extracellular vesicles, TEPs Tumor-educated platelets

conducted by Leighl et al. concluded that cfDNA testing could identify the biomarkers with a sensitivity and specificity, comparable to tissue genotyping [114]. Use of cfDNA yielded faster results and increased the biomarker discovery rate, although the median turnaround time (TAT) recorded in this study for the first 10 patients was 14 days (range, 11-30 days) and 7 days (range, 5-9 days) for the last 10 patients [114]. Often false negative results are obtained due to varied tumor localization and volume, irregular cfDNA shedding with tumor evolution [115] or patients receiving treatment [116]. A diagnostic tool comprising of a panel of miR-21, miR-126, miR-210, miR-486-5p detected NSCLC with a sensitivity and specificity of 86.2 and 96.5\% respectively [110]. The SensiScreen ${ }^{\circledR}$ EGFR Liquid kit that was commercially launched recently detects EGFR mutations (T790M, L858R, exon 19 deletions) at a higher sensitivity and specificity, which outperforms 
the established assay platforms with a robust ability to detect single copy mutations [117].

LncRNAs could serve as potential predictive and prognosis markers for EGFR resistant and mutant lung cancers as, they have been implicated in the regulation of chemosensitivity, radiosensitivity, and sensitivity of EGFR targeted therapies in lung cancers through diverse mechanisms [25]. LncRNA LINC00460 overexpression in EGFR-mutant lung adenocarcinoma was reported to be associated with poorer response to EGFR TKI therapies. Drug molecules that could target knockdown or knockout of LINC00460 may represent potential therapeutic strategy for overcoming EGFR TKIs resistance and consequently improve the prognosis of EGFR mutant lung cancer patients [118]. LncRNA bladder cancer associated transcript 1 (BLACAT1) knockdown was reported to reverse afatinib resistance in NSCLC through modulation of STAT3 signalling [119]. Several other lnRNAs such as BC087858, metastasis associated lung adenocarcinoma transcript 1 (MALAT-1) have been implicated in the promotion of EGFR TKIs resistance in lung cancer via regulation of EMT process [120]. T790M mutation detection by simultaneously capturing and interrogating exosomal RNA/DNA and cfDNA (exoNA) had 92\% sensitivity and $89 \%$ specificity using results of tumor biopsy as gold standard [26]. Another qPCR- based test that assessed mutations within EGFR using exoNA of NSCLC patients reported an overall sensitivity of $90 \%$ for L858R, $83 \%$ for $\mathrm{T} 790 \mathrm{M}$ and $73 \%$ for exon 19 indels with specificities of 100, 100, and 96\% respectively [121]. Combined approach of using exosomal RNA and ctDNA among EGFR mutant NSCLC patients improved sensitivity of EGFR mutation detection [122]. Using short length exosomal DNA and RNA (exoTNA) of $200 \mathrm{bp}$ length could potentially serve to be a sensitive biomarker for detection of EGFR mutants in NSCLC patients having low copy numbers of target mutation [123]. Several TEP biomarkers that could potentially be utilized for early screening of NSCLC have been reported [23]. Early stage and late-stage NSCLC were detected with an accuracy of 81 and $88 \%$ respectively from TEP RNA biomarker panel [124]. EGFR mutation detection in NSCLC patients was observed with $87 \%$ accuracy using the TEP-derived RNA analysis [125].

\section{Utility in detecting acquired resistance to EGFR TKIs}

EGFR T790M mutation was reported to be the primary acquired resistance to TKI therapy, followed by MET amplification, HER2 amplification and epithelial to mesenchymal transition [126, 127]. The AURA2 trial investigated the efficacy of osimeritinib, an irreversible tyrosine kinase inhibitor, in treating patients with advanced NSCLC and either EGFR-TKI sensitizing or EGFR T790M mutations. The trial demonstrated a median PFS of 9.9 months and osimertinib was well tolerated among the treated patients [128]. Consistently, the AURA Phase II extension study demonstrated a median PFS of 12.3 months with a tolerable safety profile [129]. Based on these findings, osimeritinib is now regarded in the first line of treatment in patients with EGFR T790M mutant NSCLC. Over the course of treatment with first or second-generation TKIs, patients usually acquire several mutations, including EGFR, BRAFV600E, and ERBB2 mutations; ALK, ROS1, NTRK, and RET fusion; MET amplification and MET exon 14 skipping variants that can be assessed to identify patients for subsequent targeted therapy [114].

Until recently, the only way to identify T790M status was by re-biopsy of tumor tissue. However, liquid biopsy genotyping has recently become a more appealing option to tissue re-biopsy, particularly for detecting the growing number of resistance mutations that may develop during therapy $[71,78]$. Several studies have addressed the usefulness of liquid biopsy in detecting molecular alterations that cause resistance mechanisms [130, 131]. The first report of ctDNA study with T790M in plasma was published in 2009 [132]. The identification of T790M by whole-exome sequencing of ctDNA using longitudinal blood-based EGFR testing was initially reported in 2013 [133]. Utilizing both ctDNA and CTCs, many studies have demonstrated the value of using liquid biopsies to detect EGFR resistance mutations [134-141]. Based on this finding, the NCCN and the ESMO guidelines both suggest plasma genotyping as an alternative to tissuebased testing, although secondary re-biopsy is recommended to confirm a negative plasma evaluation of T790M [6, 142]. Resistance of T790M mutants to EGFR TKIs was studied by analyzing ctDNA using CAPP-Seq in patients treated with rociletinib [141]. Chabon et al. identified a shorter PFS accompanied with novel resistance mechanism (activating KRAS, EGFR L798I) upon treatment with a third-generation TKI [141]. A study conducted by Rachiglio et al. investigated the role of concomitant driver mutations (MET, ERBB2, NRAS, BRAF, KRAS, PIK3CA) on the outcome of 133 NSCLC patients who received TKIs. Patients with concomitant driver mutations had a significantly lower PFS than those with only an EGFR mutation (7 vs. 11.3 months; $p=0.04$ ) implying that a subset of EGFR mutant tumors have concomitant driver mutations, that could affect the efficacy of first-generation EGFR TKIs [143]. Another cfDNA analysis reported that after progression on EGFR TKIs, $48.5 \%$ of plasma samples were positive for KRAS mutation, with $39.4 \%$ of those having a KRAS and EGFR co-mutation [144]. Though SCLC transformation is difficult to detect with liquid biopsy, a recent study showed 
that ctDNA can be examined in terms of changes in global copy number to track its dynamics in patients with SCLC transformation [145]. The mechanism of SCLC transformation is still largely undefined. However, it is possible that deletion of the retinoblastoma gene (RB) plays a role [146]. Completed and ongoing trials on liquid biopsy for the detection of EGFR mutant NSCLC are tabulated in the Supplementary Table 1 [147].

\section{Utility in detecting prognosis}

Tumor mutational burden (TMB), a surrogate for overall neo-antigen load [148] can be analyzed using tissue and blood-based assays. The CheckMate-026 trial reported an association between high tissue TMB (tTMB) and the clinical efficacy of nivolumab in NSCLC. An independent association between blood TMB (bTMB) and PFS prediction in patients receiving atezolizumab monotherapy was reported in NSCLC patients. The study also exemplified a high concordance between $\mathrm{BTMB}$ and tTMB when run on the same ctDNA sample [149]. A liquid biopsy with NGS can help detect tumor progression and accompanying multiple genetic alterations [150]. The trial, Tracking Non-small-Cell Lung Cancer Evolution Through Therapy (TRACERx) by Hanjani et al. analyzed chromosomal instability and genome doubling prospectively by whole exome sequencing (WES) to assess the driver events in NSCLC to predict a poor prognosis. Altered genomic co-occurrence with tumor progression was inferred to influence the patient's response to TKIs [151]. A group of advanced EGFR mutant patients were assessed for multiple co-occurring genetic alterations. cfDNA was used to identify the co-occurrence of the genetic alterations within the WNT/CTNNB1, BRAF, MET, PIK3CA, MYC, and the cell cycle pathways (CDKN2A loss and CDK6 CNG). Analysis of longitudinal tumor biopsy based whole exome sequencing and cfDNA was consistent with the genomic alterations [152]. Genomic profiling of ctDNA samples can identify therapeutic targets by locating driver and resistance mutations Analysis of the ctDNA of 8388 advanced lung adenocarcinoma and NSCLC patients by 70 gene NGS panel (Guardant360 assay) identified oncogene driver mutations in $48.8 \%$ of the samples, the most frequent mutations being EGFR followed by KRAS. The study subsequently recorded a $65 \%$ increase in biomarker detection over tissue, where one half of the patients received targeted therapy [153]. Oxnard et al. proposed plasma genotyping of cfDNA as a screening method for T790M preceding EGFR resistance biopsy. However, with a $30 \%$ false negative rate of plasma genotyping, tissue genotyping is still required for some patients. Therefore, the concomitant use of tissue and plasma genotyping is the new paradigm in determining T790M resistance management [154].

\section{Pharmacogenomics of TKIs and implications pertaining to PK/PD responses \\ Metabolism of EGFR TKIs}

EGFR TKIs are small molecules that are highly protein bound and metabolized via the CYP450 system. The majority are also substrates of P-gp and BCRP [155]. P-gp and BCRP are a family of ATP-binding cassette (ABC) transporters and are encoded by the genes $\mathrm{ABCB} 1$ and ABCG2, respectively [156, 157]. A summary of EGFR TKI metabolism is listed in Table 2. Gefitinib is a firstgeneration EGFR TKI primarily metabolized by CYP3A4, CYP2D6, and to a minor extent, CYP3A5 [158-163]. CYP1A1 may be involved in gefitinib metabolism but PK implications have yet to be characterized since CYP1A1 is typically expressed in extrahepatic locations such as the lungs [164]. Gefitinib is also known substrate of P-gp

Table 2 A summary of metabolism of EGFRTKls drugs

\begin{tabular}{|c|c|c|c|c|}
\hline EGFR TKIs & Generation & Metabolism & Drug-drug interactions & MDRP substrates \\
\hline Gefitinib & First & $\begin{array}{l}\text { CYP3A4, CYP2D6, } \\
\text { CYP3A5 (minor) }\end{array}$ & $\begin{array}{l}\text { - CYP3A4, CYP2D6 inhibitors may increase serum concentration } \\
\text { - CYP3A4, CYP2D6 inducers may decrease serum concentration }\end{array}$ & P-gp and BCRP \\
\hline Erlotinib & First & CYP1A2, CYP3A4 & $\begin{array}{l}\text { - CYP3A4, CYP2A1 inhibitors may increase serum concentration } \\
\text { - CYP3A4, CYP2A1 inducers may decrease serum concentration } \\
\text { - Erlotinib reduce serum concentrations of other CYP3A4 substrates }\end{array}$ & P-gp and BCRP \\
\hline Afatinib & First & None & $\begin{array}{l}\text { - P-gp inhibitors may increase serum concentration } \\
\text { - P-gp inducers may decrease serum concentration }\end{array}$ & P-gp and BCRP \\
\hline Dacomitinib & Second & CYP2D6 & - CYP2D6 inhibitors may increase serum concentration & None \\
\hline Osimertinib & Third & CYP3A4 & $\begin{array}{l}\text { - CYP3A4 inhibitors may increase serum concentration } \\
\text { - CYP3A4 inducers may decrease serum concentration } \\
\text { - Osimertinib may increase serum concentrations of other P-gp/BCRP substrates }\end{array}$ & P-gp and BCRP \\
\hline Mobocertinib & Third? & CYP3A4, CYP3A5 & $\begin{array}{l}\text { - CYP3A4/5 inhibitors may increase serum concentration } \\
\text { - CYP3A4/5 inducers may decrease serum concentration }\end{array}$ & Unknown \\
\hline
\end{tabular}


and BCRP [165-167]. Erlotinib is primarily metabolized by CYP1A2 and 3A4 but also induces 3A4 expression to a minor extent $[163,168]$. P-gp and BCRP may also contribute to erlotitnib clearance [169]. Afatinib is the only EGFR TKI that is not metabolized via the CYP450 system due to its strong covalent binding to plasma proteins and is primarily excreted through the feces [170, 171]. Afatinib is both a substrate and inhibitor of P-gp and BCRP $[170,172,173]$. Dacomitinib is extensively metabolized by CYP2D6 into its active metabolite, contributing to the long half-life of the drug [174]. Dacomitinib's clearance is neither known to be impacted by P-gp nor by BCRP [175]. Osimertinib is primarily metabolized by CYP3A4, and is minimally cleared by P-gp and BCRP $[176,177]$. Mobocertinib is the newest oral EGFR TKI that received accelerated approval in September 2021 by the FDA for EGFR exon 20 deletion NSCLC. Mobocertinib is metabolized by CYP3A4 and 3A5 to form two active metabolites [178]. It is unknown if mobocertinib is a P-gp or BCRP substrate at this point.

\section{Single nucleotide polymorphisms, allele frequencies and phenotypes}

Single nucleotide polymorphisms (SNPs) occur when a single DNA base differs between individuals and varies across race and ethnic groups [179]. SNPs are functionally categorized by phenotypic impact. In general, normal metabolizers (NM) are present in majority of the population and have wild type functional enzyme activity. Ultrarapid metabolizers (UM) have increased enzyme activity compared to normal metabolizers. Poor-metabolizers (PM) have limited to no enzyme activity. Intermediate metabolizers (IM) have enzyme activities between PM and NMs [180]. The phenotypic impact of SNPs in drug metabolizing enzymes can vary, ranging from benign to a significant loss or gain of enzyme activity and phenotype reporting based on ethnicity, clinical guidelines, and laboratories was inconsistent in previously published literature [181].

CYP2D6 accounts for $25 \%$ of all drug metabolism and has the most polymorphic variability in the CYP450 family [182]. In 2019, consensus guidelines recommended standardization of CYP2D6 phenotype definitions based on an activity score $[183,184]$. Notably, inconsistencies in phenotype assignments may occur due to changes to phenotype definition as more evidence become available $[182,185]$. Although CYP3A4 is the major metabolizer of drugs and its polymorphic variability has been extensively studied, there is little evidence supporting a role for CYP3A4 polymorphisms in changing the metabolism of substrates. One possible explanation could be the structural similarities between subfamilies, leading to erroneous identification of CYP3A4 [186, 187]. The CYP1A2
-163C > A SNP polymorphism (haplotype CYP1A2*1F) has increased enzyme activity for substrates such as caffeine and is the most well characterized CYP1A2 polymorphism [188]. However, at present, there is a lack of evidence for assigning CYP1A2 phenotypes due to relative infancy CYP1A2 polymorphism research. Similarly, SNP polymorphisms of $A B C B 1$ and $A B C G 2$ have been reported, however but currently, standardized definitions for phenotypes are lacking.

\section{Smoking, CYP1A2, polymorphisms and erlotinib}

Cigarette smoke produces polycyclic aromatic hydrocarbons (PAH), a class of compounds known to induce the expression of CYP1A2 [189, 190]. Several hypotheses point towards a transcriptional mechanism for CYP1A2 induction by PAH. PAH may act as a ligand for arylhydrocarbon receptor, which is an intracellular receptor involved in downstream signaling of CYP1A2 transcription [191, 192]. Another explanation may be epigenetic changes via chromatin remodeling and reduced expression of histone deacetylase 2 resulting in increased transcription of CYP1A2 [193, 194]. Induction of CYP1A2 expression increases clearance of erlotinib leading to reduced plasma exposure and subsequently lowering efficacy [195]. Even though EGFR mutations occur more frequently in non-smokers with lung cancer, managing smokers and former smokers on erlotinib treatment remains challenging clinically. Smokers and former smokers had a $3.9 \%$ response rate compared to $24.7 \%$ in a selected subset of population on erlotinib [196]. The higher number of former and current smokers may also have contributed to minimal OS benefit in the overall population. Later erlotinib trials that enrolled patients based on EGFR mutation status demonstrated significantly improved efficacy of erlotinib. However, smokers or former smokers still made up approximately $30 \%$ of the study population $[58,126,197]$ that may likely reflect the proportion of smokers or former smokers with EGFR mutated lung cancer in the real world. A pharmacokinetic model demonstrated a decrease in erlotinib exposure by more than $20 \%$ in patients exposed to cigarette smoking [198]. Another study has also showed that doubling erlotinib dose from $150 \mathrm{mg}$ to $300 \mathrm{mg}$ in current smokers resulted in similar plasma concentrations of erlotinib compared to non-smokers on $150 \mathrm{mg}$ dose, suggesting a potential need for higher doses of erlotinib to achieve adequate efficacy [199]. Based on the study by Hughes et al. up to $300 \mathrm{mg}$ once daily of erlotinib is recommended for current smokers.

Despite studies suggesting the detrimental impact of smoking on erlotinib exposure and efficacy, there are still varying extents of CYP1A2 induction by cigarette smoking that could be due to other epigenetic factors affecting 
CYP1A2 expression [200-203]. Polymorphisms in the NR1I3 gene which codes for the constitutive androstane receptor is known to upregulate the transcription of CYP1A2 [200, 204]. Constitutive androstane receptor is also known to interact with the PAH pathway of CYP1A2 induction. Another epigenetic factor may be due to the influence of methylation on CYP1A2 expression in hepatocytes [205]. Previous literature also suggests that certain CYP1A2 polymorphisms such as CYP1A2*1F may be induced to a larger extent in smokers [202, 203]. Contributions to erlotinib metabolism by CYP3A4, P-gp, and BCRP, may also explain the variation in CYP1A2 induction by cigarette smoke. Therefore, there is currently limited recommendation for phenotype definition and lack of guidelines for CYP1A2 based PGx testing with erlotinib use.

\section{Polymorphisms in CYP3A4}

Phenotyping studies assessing the effect of CYP3A4 variants on erlotinib metabolism were inconclusive and pre-emptive testing is not currently recommended. A PK study in a Korean population showed no difference in AUC exposure and $C_{\max }$ of erlotinib in patients with CYP3A4 polymorphisms [206]. In a similar study, a polymorphism in CYP1A2*1 $\mathrm{M}$ resulted in a higher $\mathrm{C}_{\max }$. One explanation for the lack of evidence for supporting PGx guided dosing for erlotinib may be due to multiple metabolic pathways involved in erlotinib clearance. Another contributing factor could be auto-induction of CYP3A4 by erlotinib. CYP450 induction often occurs on a transcriptional level and takes up to 2 weeks for increased expression, which may be missed in studies that do not assess steady state erlotinib levels [206, 207]. There are limited studies evaluating the impact of CYP3A4 SNPs and gefitinib, osimertinib, and mobocertinib metabolism. Furthermore, there is a lack of evidence suggesting that CYP3A4 polymorphisms alter PK/PD parameters of EGFR TKIs. Similar to CYP1A2, phenotypes for CYP3A4 are yet to be defined and there is lack of guidance supporting testing for CYP3A4 polymorphisms to guide dosing of EGFR TKIs.

\section{Polymorphisms in CYP2D6}

Numerous studies have evaluated associations of gefitinib adverse effects, such as rash and hepatotoxicity, in patients who have reduced CYP2D6 metabolizing phenotypes. A study enrolled Japanese patients who developed transaminitis after starting gefitinib, but did not find significant differences in CYP2D6 polymorphisms [208, 209]. Similarly, another study assessing Japanese patients who were extensive metabolizers (EM) and IMs of CYP2D6 found higher active metabolite concentrations, but higher concentrations were not associated with increased adverse effects [209]. In a third study in Japanese patients, Suzumura et al. reported patients with CYP2D6 *10/*10 polymorphism, defined as a reduced activity phenotype, had an increased risk of rash with gefitinib compared to patients on erlotinib [210]. The conflicting evidence supporting a relationship between increased gefitinib adverse effects and CYP2D6 polymorphisms are multifactorial. This may partly be explained by the fact that previous studies utilized the EM or rapid metabolizer phenotype of CYP2D6, which has been removed and re-classified under NM [183]. The lack of standardized CYP2D6 definitions that may also have contributed to differences in testing and selection of alleles of interest remains a challenge today [211]. A recent study of dacomitinib in Chinese patients with IM and EM CYP2D6 polymorphisms found insignificant changes to exposure of primary metabolite of dacomitinib between the two groups [212]. However, it was noted by the authors that CYP2D6 EM in the Chinese population had a $53.5 \%$ metabolite to parent exposure ratio compared to 25.4\% in a Western CYP2D6 EM population, suggesting that polymorphism and PGx testing may be impacted by ethnicity.

\section{Polymorphisms in $A B C B 1$ and $A B C G 2$}

P-gp and BCRP are primarily expressed along the luminal intestinal wall and blood brain barrier and prevent diffusion of xenobiotics across membranes into the blood circulation and central nervous system, respectively [31]. Polymorphisms in ABCB1 and ABCG2, have been shown to correlate with expression of P-gp and $\mathrm{BCRP}$, respectively. $\mathrm{ABCB} 1$ and $\mathrm{ABCG} 2$ polymorphisms resulting in increased expression of P-gp and BCRP may reduce bioavailability of a substrates like gefitinib, erlotinib, afatinib and osimertinib resulting in lower systemic exposure $[213,214]$. On the other hand, reduced expression of P-gp and BCRP has been purported to increase bioavailability resulting in increased toxicities $[167,215]$. Endo-Tsukude et al. reported marginal increase in rash among Japanese patients harboring ABCB1 1236C > T genotypes, however the differences were not significant [216]. A study led by Fukudo and colleagues found that Japanese patients harbouring ABCG2 421C > A SNP polymorphism had increased plasma exposure of erlotinib which is associated with increased diarrhea [217]. However, another study in Japanese patients by Akasaka et al. did not find an increased risk of diarrhea in patients with ABCG2 421C > A polymorphism [218].

An increase in P-gp and BCRP activity or expression along the luminal membrane of the blood brain barrier may decrease central nervous system (CNS) penetration of EGFR TKIs. In vitro and preclinical models of gefitinib, [165, 166] erlotinib, [219-221] and osimertinib [177] 
have suggested that less CNS penetration was achieved in patients with increased expression of P-gp and BCRP. A decrease in CNS penetration can have detrimental impacts on patients with CNS metastases, which confers poorer prognosis. Alternatively, a decreased expression of P-gp and BCRP may theoretically increase CNS toxicity although there is no evidence published yet.

In addition to germline PGx differences in P-gp and BCRP, cancer cells have been shown to upregulate expression of these transporters and prevent chemotherapy from reaching their intracellular target tissue. Increased P-gp and BCRP contributes to chemoresistance and subsequent treatment failure.

Current evidence does not support a role for pharmacogenetic dose adjustment of EGFR TKIs. Available studies are usually small, with variable methodologies and conflicting results. Larger studies that comprehensively evaluate the impact of polymorphisms on drug exposure and outcome are needed to optimize precision dosing as shown in Fig. 3.

\section{Alternative strategies and future directions}

It is generally accepted that plasma concentrations are associated with drug effects, both efficacy and toxicity. While SNPs contribute to drug plasma concentrations, a variety of other factors, including drug-drug interactions, food effects, and body size are other contributing factors. By directly measuring drug concentrations, and adjusting dose based on concentration, therapeutic dose monitoring (TDM) can potentially overcome factors that limit the utility of PGx testing. Many analytical methods are reported for erlotinib, [222-225] gefitinib [225-229] and osimertinib [230, 231]. Despite the abundance of methods for detecting EGFR TKI plasma concentrations, TDM of EGFR TKIs are not yet clinically validated or implemented routinely in practice. Identification of a target concentration associated with activity, as well as clinical trials demonstrating that TDM outperforms routine clinical care is required prior to clinical implementation.

Cancer cells are known to develop chemoresistance through upregulation of $\mathrm{ABCB} 1$ and $\mathrm{ABCG} 2$ expression,

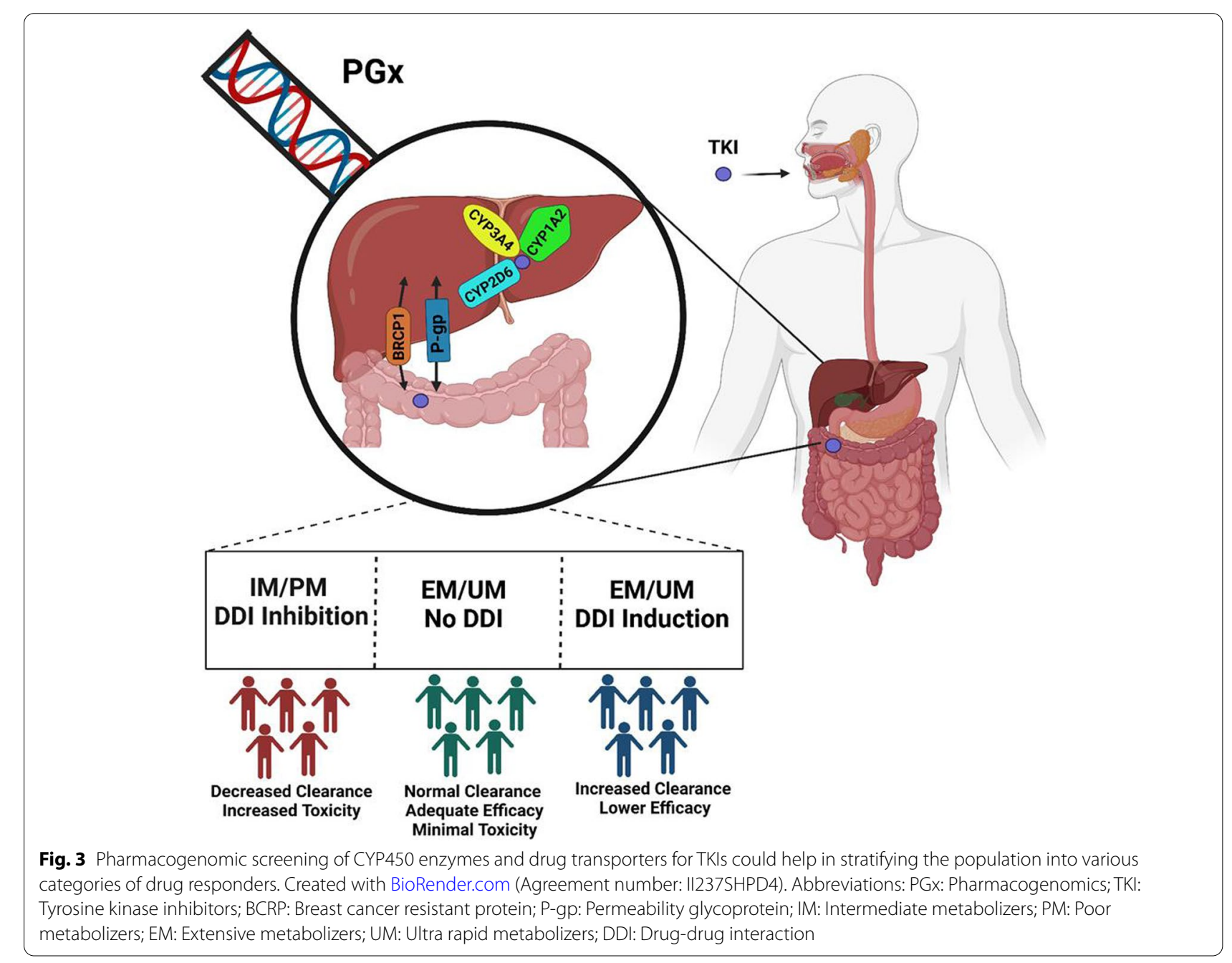


preventing chemotherapy from reaching the target tissue. Gefitinib, erlotinib, afatinib, and osimertinib, are substrates of P-gp and BCRP, and a potential strategy is to combine these agents with P-gp inhibitors, thereby resensitizing tumors to chemotherapy. Ongoing studies are required to develop these potentially effective combinations. Liquid biopsies can complement such synergistic strategies in clinical practice by testing for upregulation in P-gp and BCRP expression throughout a patient's treatment.

Traditionally, early phase dose finding clinical trials rely upon a " $3+3$ " maximum tolerated dose design. The paradigm shift toward targeted therapy has called for different approaches for optimizing targeted therapy dosing [232]. Preclinical models of targeted therapies utilize receptor saturation or inhibition of phosphorylation activities during the drug development process. It has been shown that EGFR saturation in preclinical models corresponds to anti-tumor efficacy [233]. A small number of studies, including gefitinib, have utilized EGFR receptor saturation as part of an endpoint in phase 1 studies [234-236]. However, it is unclear if adequate EGFR receptor saturation is correlated to efficacy and toxicity and receptor turnover as a result of EGFR TKIs binding, as there is a potential limitation in measuring receptor saturation due to the short half-life of about $12 \mathrm{~h}[237,238]$.

Immunotherapy has been explored as an alternative or complementary therapeutic strategy among lung cancer patients, particularly in those with TKIs resistance and/or in advanced stages of EGFR mutant lung cancers and are unaffected by the genetic polymorphisms of drug metabolizing enzymes and/or transporters [239, 240]. EGFR-directed monoclonal antibodies such as cetuximab, necitumumab, panitumumab, matuzumab and nimotuzumab can bind on to EGFR present on the surface of tumor cells and prevent the binding of the ligand epidermal growth factor (EGF) in the extracellular domain, resulting in inhibition of EGFR signalling. These monoclonal antibodies could also inhibit EGFR signaling by other mechanisms including antibody dependent cellular toxicity (ADCC) [241]. However, lack of significant clinical benefits with the combination therapy of EGFR-directed monoclonal antibodies with TKIs in EGFR mutant lung cancer patients warrants the need for further evidence [242]. Immune check point inhibitors (ICIs), comprising of monoclonal antibodies against programmed cell death protein-1 (PD-1) such as nivolumab, pembrolizumab and programmed death-ligand1 (PDL1) such as atezolimumab and durvalumab, have been reported to improve the clinical response in few subsets of lung cancer patients. However, majority of the available reports suggest that EGFR-mutant lung cancer patients have shown poorer response to ICIs treatment
[243-246]. Several factors such as lower PD-L1 expression and tumor mutational burden, increased risk of pulmonary toxicity in patients on prior or concurrent osimertinib therapy, limited efficacy with ICIs monotherapy and risk of developing hyper-progressive disease (HPD), warrant caution for their use in EGFR mutant lung cancer patients [246, 247].

\section{Challenges of liquid biopsy-based detection and PGx of EGFR mutation and resistant lung cancer}

EGFR T790M mutation accounts for only about half of the resistance mechanisms in NSCLC patients who developed acquired resistance to first or second-generation TKIs. Liquid biopsy may not be able to detect other resistance mechanisms, such as small cell cancer transformation [80]. Several rare EGFR mutations are known to cause conformational alterations in the EGFR drug binding region. However, their influence on TKIs responses is still debated and require further clinical validation [248, 249]. Some liquid biopsy assays have been reported to have a lower sensitivity for EGFR mutations compared to tissue biopsy that may be attributed to sampling from different tumor cell populations as well as differing sequencing technologies $[137,250]$. An increased frequency of EGFR T790M detection correlated with tumor progression/ metastasis by liquid biopsy and is explained by low copy number in peripheral blood in early stage, that may pose problems for early screening of lung cancer by liquid biopsy [138, 251]. Further, the TMB in EGFR-mutated tumors was shown to be significantly lower than in EGFR wild-type tumors [252]. Robust implementation of liquid biopsy as a clinical tool in the management of EGFR resistant lung cancer warrants further harmonization of the diverse ctDNA analysis technologies and different platforms, and requires multicentric randomized controlled trials with larger cohorts of patients and controls [253]. Harmonization of PGx guidelines among different consortia and agencies and lack of compliance among physicians for PGx label-based testing and prescribing present key challenges in the implementation of pharmacogenomicsbased therapy management in clinics [254]. PGx does not offer information on the post-translational modifications of encoded proteins, therefore the importance of this element in cancer therapy requires additional investigations [255]. Implications of other interacting factors on genetic polymorphisms of CYP450 enzymes and drug transporters such as various patient specific factors, ethnicity, epigenomics, lifestyle, drug-drug and drug-dietary interactions could pose challenges in deriving appropriate genotyping-based dosage implementation at an individual level in clinics [255-257]. Most importantly, 


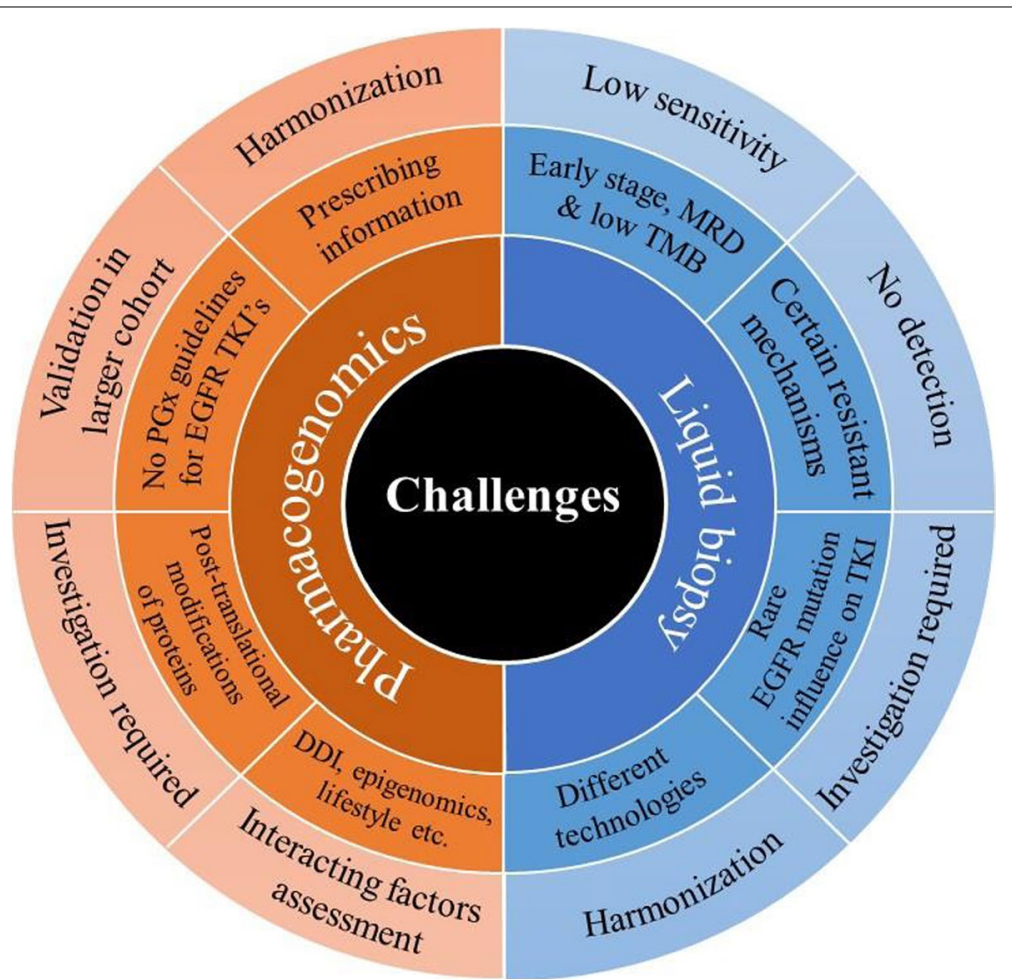

Fig. 4 Challenges faced by liquid biopsy and PGx for their implementation in clinical practice for EGFR resistant and mutant lung cancer patients. Abbreviations: PGx: Pharmacogenomics; EGFR: Epidermal growth factor receptor; TKIs: Tyrosine kinase inhibitors; PTM: Post translational modifications; DDI: Drug-drug interaction; MRD: Minimal residual disease; TMB: Tumor mutational burden

currently there is a lack of guidelines supporting testing of CYP450 and drug transporter polymorphisms to guide dosing of EGFR TKIs. A summary of these limitations is represented in Fig. 4.

\section{Conclusion}

While tissue remains the most accepted material for molecular profiling of solid tumors such as lung cancers, it is limited by the dynamic and heterogenous nature of cancer resulting in spontaneous occurrence of clonal evolution and drug resistance. Liquid biopsy has emerged as an imperative alternative and/or complementary tool to tissue biopsy for molecular profiling in lung cancer due to its relative advantages such as being minimally invasive, reduced procedural complications, as well as its utility for longitudinal monitoring of patients for monitoring acquired resistance to TKIs. An integrated approach of employing liquid biopsy and PGx for serial molecular profiling of EGFR mutant and resistant lung cancer patients at an individual level as well as at population subsets could represent a potential precise screening and monitoring tool in this era of precision oncology by identifying precise doses of TKIs against targetable EGFR mutations. Though significant progress has been made in these fields, several aspects related to their successful implementation in practice, such as framing of robust guidelines, harmonization of sequencing technologies and platforms, multicentric validation in larger patient cohorts, and identification of various interacting factors needs to be addressed before clinical adoption at a global scale.

\section{Abbreviations}

ABC: Adenosine triphosphate binding cassette; $A B C B 1$ : Adenosine triphosphate binding cassette subfamily B member 1; ABCG2: Adenosine triphosphate binding cassette subfamily G member 2; ADCC: Antibody dependent cellular toxicity; AKT: Ak strain transforming murine thymoma viral oncogene homolog; ALK: Anaplastic lymphoma kinase; ASCO: American Society of Clinical Oncology; ATP: Adenosine triphosphate; AUC: Area under the curve; AXL: Anexelekto; BCRP: Breast cancer resistant protein; BLACAT1: Bladder cancer associated transcript 1; BRAF: Rapidly accelerated fibrosarcoma viral oncogene homolog B1; BRAFV600E: B-Raf proto-oncogene; valine (V) is substituted by glutamic acid (E); bTMB: Blood tumor mutational burden; CAPP-Seq: Cancer personalized profiling by deep sequencing; ccfDNA: Circulating cell free DNA; CDK6 CNG: Cyclin-dependent kinase 6 copy number gain; CDK6: Cyclindependent kinase 6; CDKN2A: Cyclin-dependent kinase inhibitor 2A; cfDNA: Cell free DNA; circRNA: Circular RNA; Cmax: Maximum serum concentration; C-MET: Mesenchymal epithelial transition factor; CNS: Central nervous system; CTCs: Circulating tumor cells; ctDNA: Circulating tumor DNA; CTNNB1: Catenin beta1; ctRNA: Circulating tumor RNA; CYP450: Cytochrome P450; DDI: Drug drug interaction; ddPCR: Digital droplet polymerase chain reaction; DNA: Deoxyribonucleic acid; dPCR: Digital polymerase chain reaction; E-Cadherin: Epithelial cadherin; EDTA: Ethylenediamine tetraacetic acid; EFIRM: Electric field-induced release and measurement; EGF: Epidermal growth factor; EGFR: Epidermal growth factor receptor; EM: Extensive metabolizers; EpCAM: Epithelial cell adhesion molecule; ErbB: Erythroblastic leukemia viral oncogene homologue; ERBB2: Erythroblastic leukemia viral oncogene homolog 2; ERBB3: 
Erythroblastic leukemia viral oncogene homolog 3; ERK: Extracellular signal regulated kinase; ESMO: European Society for Medical Oncology; EVs: Extracellular vesicles; ExoNA: Exosomal RNA/DNA and cfDNA; ExoTNA: Exosomal DNA and RNA; FDA: Food and Drug Administration; HER2: Human epidermal growth factor receptor 2; HGF: Hepatocyte growth factor; HPD: Hyperprogressive disease; ICls: Immune check point inhibitors; IM: Intermediate metabolizers; JAK: Janus activated kinase; KRAS: Kirsten rat sarcoma; IncRNA: Long non-coding RNA; MALAT-1: Metastasis associated lung adenocarcinoma transcript 1; MAPK: Mitogen-activated protein kinase; MDRPs: Multi-drug resistant transporter proteins; MEK: Mitogen-activated protein kinase kinase; MET: Mesenchymal epithelial transition factor; miRNA: MicroRNA; MRD: Minimal residual disease; mRNA: Messenger RNA; mTOR: Mammalian target of rapamycin; NCCN: National Comprehensive Cancer Network; NGS: Next generation sequencing; NM: Normal metabolizers; NR1 I3: Nuclear receptor subfamily 1 group I member 3; NSCLC: Non-small cell lung cancer; NTRK: Neurotrophic tropomyosin receptor kinase; ORR: Overall response rate; OS: Overall survival; PAH: Polycyclic aromatic hydrocarbons; PD: Pharmacodynamic; PD-1: Programmed cell death protein-1; PD-L1: Programmed death-ligand 1; PFS: Progression-free survival; P-gp: Permeability glycoprotein; PGx: Pharmacogenomic; PIK3CA: Phosphatidylinositol 4,5-bisphosphate 3-kinase catalytic subunit alpha isoform; PK: Pharmacokinetic; PM: Poor metabolizers; PTMs: Post translational modifications; qPCR: Quantitative polymerase chain reaction; RAF: Rapidly accelerated fibrosarcoma; RAS: Rat sarcoma virus; RB: Retinoblastoma; RCTs: Randomized controlled trials; RECIST: Response Evaluation Criteria in Solid Tumors; RET: Rearranged during transfection; RNA: Ribonucleic acid; ROS1: Receptor tyrosine kinase; RT-qPCR: Quantitative real-time polymerase chain reaction; SCLC: Small-cell lung cancer; SNPs: Single nucleotide polymorphisms; STAT3: Signal transducer and activator of transcription 3; TAT :Turnaround time; TDM: Therapeutic drug monitoring; TEPs: Tumor educated platelets; TKIs: Tyrosine kinase inhibitors; TMB: Tumor mutational burden; TRACERx: Tracking non-small-cell lung cancer evolution through therapy; tTMB: Tissue tumor mutational burden; UM: Ultra rapid metabolizers; WBC: White blood cell; WES: Whole exome sequencing; WHO: World Health Organization; WNT: Wingless-related integration site; ZEB1: Zinc finger E-box-binding homeobox 1.

\section{Supplementary Information}

The online version contains supplementary material available at https://doi. org/10.1186/s12943-022-01534-8.

Additional file 1: Supplementary Table 1. Completed and ongoing trials on liquid biopsy for the detection of EGFR mutant NSCLC.

\section{Acknowledgements}

"Not applicable".

\section{Authors' contributions}

MR, LT and JK designed, and MR, SP, JK, LT, GB, NM, RK wrote the manuscript. $\mathrm{KU}, \mathrm{NK}, \mathrm{SS}, \mathrm{AP}$ and VMR reviewed, edited and approved the final version of the manuscript. The authors read and approved the final manuscript.

\section{Funding}

"Not applicable".

Availability of data and materials

"Not applicable".

\section{Declarations}

Ethics approval and consent to participate

"Not applicable".

\section{Consent for publication}

"Not applicable".

\section{Competing interests}

"The authors declare that they have no competing interests" in this section.

\section{Author details}

${ }^{1}$ Department of Pharmacy Practice \& Science, University of Kentucky, Lexington, KY 40536, USA. ${ }^{2}$ Department of Pharmacy Practice, Manipal College of Pharmaceutical Sciences, Manipal Academy of Higher Education, Manipal, Karnataka 576104, India. ${ }^{3}$ Department of Radiotherapy and Oncology, Kasturba Medical College, Manipal Comprehensive Cancer Care Centre, Manipal Academy of Higher Education, Manipal, Karnataka 576104, India. ${ }^{4}$ Department of Medical Oncology, Kasturba Medical College, Manipal Comprehensive Cancer Care Centre, Manipal Academy of Higher Education, Manipal, Karnataka 576104, India. ${ }^{5}$ Department of Surgical Oncology, Kasturba Medical College, Manipal Comprehensive Cancer Care Centre, Manipal Academy of Higher Education, Manipal, Karnataka 576104, India. ${ }^{6}$ Markey Cancer Centre and Department of Radiation Medicine, University of Kentucky, Lexington, KY 40536, USA.

Received: 30 November 2021 Accepted: 7 February 2022

Published online: 24 February 2022

\section{References}

1. Sung H, Ferlay J, Siegel RL, Laversanne M, Soerjomataram I, Jemal A, et al. Global cancer statistics 2020: GLOBOCAN estimates of incidence and mortality worldwide for 36 cancers in 185 countries. CA Cancer J Clin. 2021;71(3):209-49.

2. Rizvi H, Sanchez-Vega F, La K, Chatila W, Jonsson P, Halpenny D, et al. Molecular determinants of response to anti-programmed cell death (PD)-1 and anti-programmed death-ligand 1 (PD-L1) blockade in patients with non-small-cell lung cancer profiled with targeted nextgeneration sequencing. J Clin Oncol. 2018;36(7):633-41.

3. Campbell JD, Alexandrov A, Kim J, Wala J, Berger AH, Pedamallu CS, et al. Distinct patterns of somatic genome alterations in lung adenocarcinomas and squamous cell carcinomas. Nat Genet. 2016;48(6):607-16.

4. Hellmann MD, Nathanson T, Rizvi H, Creelan BC, Sanchez-Vega F, Ahuja A, et al. Genomic features of response to combination immunotherapy in patients with advanced non-small-cell lung cancer. Cancer Cell. 2018;33(5):843-52 e4.

5. Yoshida T, Zhang G, Haura EB. Targeting epidermal growth factor receptor: central signaling kinase in lung cancer. Biochem Pharmacol. 2010;80(5):613-23.

6. Ettinger DS, Wood DE, Aggarwal C, Aisner DL, Akerley W, Bauman JR, et al. NCCN guidelines insights: non-small cell lung cancer, version 1.2020: featured updates to the NCCN guidelines. J Natl Compr Cancer Netw. 2019;17(12):1464-72.

7. Lindeman NI, Cagle PT, Aisner DL, Arcila ME, Beasley MB, Bernicker EH, et al. Updated molecular testing guideline for the selection of Lung Cancer patients for treatment with targeted tyrosine kinase inhibitors: guideline from the College of American Pathologists, the International Association for the Study of Lung Cancer, and the Association for Molecular Pathology. Arch Pathol Lab Med. 2018;142(3):321-46.

8. Esagian SM, Grigoriadou GI, Nikas IP, Boikou V, Sadow PM, Won J-K, et al. Comparison of liquid-based to tissue-based biopsy analysis by targeted next generation sequencing in advanced non-small cell lung cancer: a comprehensive systematic review. J Cancer Res Clin Oncol. 2020;146:2051-66.

9. MokTS, Wu Y-L, Ahn M-J, Garassino MC, Kim HR, Ramalingam SS, et al. Osimertinib or platinum-pemetrexed in EGFR T790M-positive lung cancer. N Engl J Med. 2017;376(7):629-40.

10. Zhou J, Zhao C, Zhao J, Wang Q, Chu X, Li J, et al. Re-biopsy and liquid biopsy for patients with non-small cell lung cancer after EGFRtyrosine kinase inhibitor failure. Thorac Cancer. 2019;10(4):957-65.

11. Cavic M, Krivokuca A, Pavlovic M, Boljevic I, Rakobradovic J, Mihajlovic $M$, et al. EGFR mutation testing from liquid biopsy of non-small cell lung cancer at the Institute for Oncology and Radiology of Serbia. J BUON. 2020;25(6):2635-42.

12. Nakamura T, Nakashima C, Komiya K, Kitera K, Hirai M, Kimura S, et al. Mechanisms of acquired resistance to afatinib clarified with liquid biopsy. PLoS One. 2018;13(12):e0209384.

13. Mathai RA, Vidya RVS, Reddy BS, Thomas L, Udupa K, Kolesar J, et al. Potential utility of liquid biopsy as a diagnostic and prognostic tool for the assessment of solid tumors: implications in the precision oncology. J Clin Med. 2019;8(3):373. 
14. Palmirotta R, Lovero D, Cafforio P, Felici C, Mannavola F, Pellè E, et al. Liquid biopsy of cancer: a multimodal diagnostic tool in clinical oncology. Ther Adv Med Oncol. 2018;10:1758835918794630.

15. Michela B. Liquid biopsy: a family of possible diagnostic tools. Diagnostics (Basel). 2021;11(8):1391.

16. Thompson JC, Yee SS, Troxel AB, Savitch SL, Fan R, Balli D, et al. Detection of therapeutically targetable driver and resistance mutations in lung cancer patients by next-generation sequencing of cell-free circulating tumor DNA. Clin Cancer Res. 2016;22(23):5772-82.

17. Guibert N, Hu Y, Feeney N, Kuang Y, Plagnol V, Jones G, et al. Amplicon-based next-generation sequencing of plasma cell-free DNA for detection of driver and resistance mutations in advanced non-small cell lung cancer. Ann Oncol. 2018;29(4):1049-55.

18. Tong $B, X u$ Y, Zhao J, Chen $M$, Zhong W, Xing J, et al. Prognostic role of circulating tumor cells in patients with EGFR-mutated or ALK-rearranged non-small cell lung cancer. Thorac Cancer. 2018;9(5):640-5.

19. Haranguș A, Berindan-Neagoe I, Todea DA, Șimon I, Șimon M. Noncoding RNAs and liquid biopsy in Lung Cancer: a literature review. Diagnostics (Basel). 2019;9(4):216.

20. Zhou Y, Zheng X, Xu B, Chen L, Wang Q, Deng H, et al. Circular RNA hsa_circ_0004015 regulates the proliferation, invasion, and TKI drug resistance of non-small cell lung cancer by miR-1183/PDPK1 signaling pathway. Biochem Biophys Res Commun. 2019;508(2):527-35.

21. Joseph NA, Chiou S-H, Lung Z, Yang C-L, Lin T-Y, Chang H-W, et al. The role of HGF-MET pathway and CCDC66 cirRNA expression in EGFR resistance and epithelial-to-mesenchymal transition of lung adenocarcinoma cells. J Hematol Oncol. 2018;11(1):1-14.

22. Nilsson RJA, Karachaliou N, Berenguer J, Gimenez-Capitan A, Schellen P, Teixido C, et al. Rearranged EML4-ALK fusion transcripts sequester in circulating blood platelets and enable blood-based crizotinib response monitoring in non-small-cell lung cancer. Oncotarget. 2016;7(1):1066-75.

23. Sheng M, Dong Z, Xie Y. Identification of tumor-educated platelet biomarkers of non-small-cell lung cancer. Onco Targets Ther. 2018;11:8143-51.

24. Clark DJ, Fondrie WE, Yang A, Mao L. Triple SILAC quantitative proteomic analysis reveals differential abundance of cell signaling proteins between normal and lung cancer-derived exosomes. J Proteome. 2016;133:161-9.

25. Chen Y, Zitello E, Guo R, Deng Y. The function of LncRNAs and their role in the prediction, diagnosis, and prognosis of lung cancer. Clin Transl Med. 2021;11(4):e367.

26. Castellanos-Rizaldos E, Grimm DG, Tadigotla V, Hurley J, Healy $J$, Neal PL, et al. Exosome-based detection of EGFR T790M in plasma from non-small cell lung cancer patients. Clin Cancer Res. 2018;24(12):2944-50.

27. Baburaj G, Damerla RR, Udupa KS, Parida P, Munisamy M, Kolesar J, et al. Liquid biopsy approaches for pleural effusion in lung cancer patients. Mol Biol Rep. 2020;47(10):8179-87.

28. Zanger UM, Turpeinen M, Klein K, Schwab M. Functional pharmacogenetics/genomics of human cytochromes P450 involved in drug biotransformation. Anal Bioanal Chem. 2008;392(6):1093-108.

29. Rodriguez-Antona C, Ingelman-Sundberg M. Cytochrome P 450 pharmacogenetics and cancer. Oncogene. 2006;25(11):1679-91.

30. McDonnell AM, Dang CH. Basic review of the cytochrome p450 system. J Adv Pract Oncol. 2013;4(4):263-8.

31. Borst $\mathrm{P}$, Evers $\mathrm{R}$, Kool M, Wijnholds J. A family of drug transporters: the multidrug resistance-associated proteins. J Natl Cancer Inst. 2000;92(16):1295-302.

32. Pérez-Ramírez C, Cañadas-Garre M, Molina MÁ, Barrera JC, Faus-Dáder MJ. Impact of single nucleotide polymorphisms on the efficacy and toxicity of EGFR tyrosine kinase inhibitors in advanced non-small cell lung cancer patients. Mutat Res Rev Mutat Res. 2019;781:63-70.

33. Slavin TP, Banks KC, Chudova D, Oxnard GR, Odegaard Jl, Nagy RJ, et al. Identification of incidental germline mutations in patients with advanced solid tumors who underwent cell-free circulating tumor DNA sequencing. J Clin Oncol. 2018;36(35):3459.

34. Lax I, Burgess WH, Bellot F, Ullrich A, Schlessinger J, Givol D. Localization of a major receptor-binding domain for epidermal growth factor by affinity labeling. Mol Cell Biol. 1988;8(4):1831-4.
35. Yoneda $\mathrm{K}$, Imanishi $\mathrm{N}$, Ichiki Y, Tanaka F. Treatment of non-small cell lung cancer with EGFR-mutations. J UOEH. 2019;41(2):153-63.

36. Wee P, Wang Z. Epidermal growth factor receptor cell proliferation signaling pathways. Cancers (Basel). 2017;9(5):52.

37. Dokala A, Thakur S. Extracellular region of epidermal growth factor receptor: a potential target for anti-EGFR drug discovery. Oncogene. 2017:36(17):2337-44.

38. Ullrich A, Coussens L, Hayflick JS, Dull TJ, Gray A, Tam A, et al. Human epidermal growth factor receptor CDNA sequence and aberrant expression of the amplified gene in A431 epidermoid carcinoma cells. Nature. 1984;309(5967):418-25.

39. Ogiso H, Ishitani R, Nureki O, Fukai S, Yamanaka M, Kim J-H, et al. Crystal structure of the complex of human epidermal growth factor and receptor extracellular domains. Cell. 2002;110(6):775-87.

40. Rosell R, Moran T, Queralt C, Porta R, Cardenal F, Camps C, et al. Screening for epidermal growth factor receptor mutations in lung cancer. $\mathrm{N}$ Engl J Med. 2009;361(10):958-67.

41. Shi Y, Au JS-K, Thongprasert S, Srinivasan S, Tsai C-M, Khoa MT, et al. A prospective, molecular epidemiology study of EGFR mutations in Asian patients with advanced non-small-cell lung cancer of adenocarcinoma histology (PIONEER). J Thorac Oncol. 2014;9(2):154-62.

42. Cho J, Chen L, Sangji N, Okabe T, Yonesaka K, Francis JM, et al. Cetuximab response of lung cancer-derived EGF receptor mutants is associated with asymmetric dimerization. Cancer Res. 2013;73(22):6770-9.

43. MokTS, Wu Y-L, Thongprasert S, Yang C-H, Chu D-T, Saijo N, et al. Gefitinib or carboplatin-paclitaxel in pulmonary adenocarcinoma. N Engl J Med. 2009;361(10):947-57.

44. Maemondo M, Inoue A, Kobayashi K, Sugawara S, Oizumi S, Isobe H, et al. Gefitinib or chemotherapy for non-small-cell lung cancer with mutated EGFR. N Engl J Med. 2010;362(25):2380-8.

45. Sequist LV, Yang JC, Yamamoto N, O'Byrne K, Hirsh V, MokT, et al. Phase III study of afatinib or cisplatin plus pemetrexed in patients with metastatic lung adenocarcinoma with EGFR mutations. J Clin Oncol. 2013;31(27):3327-34

46. Wu Y-L, Zhou C, Hu C-P, Feng J, Lu S, Huang Y, et al. Afatinib versus cisplatin plus gemcitabine for first-line treatment of Asian patients with advanced non-small-cell lung cancer harbouring EGFR mutations (LUX-Lung 6): an open-label, randomised phase 3 trial. Lancet Oncol. 2014;15(2):213-22.

47. Planchard D, Popat S, Kerr K, Novello S, Smit E, Faivre-Finn C, et al. Metastatic non-small cell lung cancer: ESMO clinical practice guidelines for diagnosis, treatment and follow-up. Ann Oncol. 2018;29:iv192-237.

48. Kalemkerian GP, Narula N, Kennedy EB, Biermann WA, Donington J, Leighl NB, et al. Molecular testing guideline for the selection of patients with lung cancer for treatment with targeted tyrosine kinase inhibitors: American Society of Clinical Oncology endorsement of the College of American Pathologists/International Association for the Study of Lung Cancer/Association for Molecular Pathology Clinical Practice Guideline Update. J Clin Oncol. 2018;36(9):911-9.

49. Kris MG, Johnson BE, Berry LD, Kwiatkowski DJ, lafrate AJ, Wistuba II, et al. Using multiplexed assays of oncogenic drivers in lung cancers to select targeted drugs. JAMA. 2014;311(19):1998-2006.

50. Hanna NH, Robinson AG, Temin S, Baker S Jr, Brahmer JR, Ellis PM, et al. Therapy for stage IV non-small-cell lung cancer with driver alterations: ASCO and $\mathrm{OH}$ (CCO) joint guideline update. J Clin Oncol. 2021;39(9):1040-91.

51. National Comprehensive Cancer Network Non-small cell lung cancer (version 8.2020-September 15, 2020). https://www.nccn.org/profession als/physician_gls/pdf/nscl.pdf. Accessed 18 Sept 2021.

52. Recondo G, Facchinetti F, Olaussen KA, Besse B, Friboulet L. Making the first move in EGFR-driven or ALK-driven NSCLC: first-generation or nextgeneration TKI? Nat Rev Clin Oncol. 2018;15(11):694-708.

53. Nguyen K-SH, Kobayashi S, Costa DB. Acquired resistance to epidermal growth factor receptor tyrosine kinase inhibitors in non-small-cell lung cancers dependent on the epidermal growth factor receptor pathway. Clin Lung Cancer. 2009;10(4):281-9.

54. Fukuoka M, Wu Y-L, Thongprasert S, Sunpaweravong P, Leong S-S, Sriuranpong $V$, et al. Biomarker analyses and final overall survival results from a phase III, randomized, open-label, first-line study of gefitinib versus carboplatin/paclitaxel in clinically selected patients 
with advanced non-small-cell lung cancer in Asia (IPASS). J Clin Oncol. 2011;29(21):2866-74.

55. Lynch TJ, Bell DW, Sordella R, Gurubhagavatula S, Okimoto RA, Brannigan BW, et al. Activating mutations in the epidermal growth factor receptor underlying responsiveness of non-small-cell lung cancer to gefitinib. N Engl J Med. 2004;350(21):2129-39.

56. Paez JG, Jänne PA, Lee JC, Tracy S, Greulich H, Gabriel S, et al. EGFR mutations in lung cancer: correlation with clinical response to gefitinib therapy. Science. 2004;304(5676):1497-500.

57. Pao W, Miller V, Zakowski M, Doherty J, Politi K, Sarkaria I, et al. EGF receptor gene mutations are common in lung cancers from "never smokers" and are associated with sensitivity of tumors to gefitinib and erlotinib. Proc Natl Acad Sci U S A. 2004;101(36):13306-11.

58. Rosell R, Carcereny E, Gervais R, Vergnenegre A, Massuti B, Felip E, et al. Erlotinib versus standard chemotherapy as first-line treatment for European patients with advanced EGFR mutation-positive non-smallcell lung cancer (EURTAC): a multicentre, open-label, randomised phase 3 trial. Lancet Oncol. 2012;13(3):239-46.

59. Mitsudomi T, Morita S, Yatabe Y, Negoro S, Okamoto I, Tsurutani J, et al. Gefitinib versus cisplatin plus docetaxel in patients with non-small-cell lung cancer harbouring mutations of the epidermal growth factor receptor (WJTOG3405): an open label, randomised phase 3 trial. Lancet Oncol. 2010;11(2):121-8.

60. Zhou C, Wu Y-L, Chen G, Feng J, Liu X-Q, Wang C, et al. Erlotinib versus chemotherapy as first-line treatment for patients with advanced EGFR mutation-positive non-small-cell lung cancer (OPTIMAL, CTONG-0802): a multicentre, open-label, randomised, phase 3 study. Lancet Oncol. 2011;12(8):735-42.

61. Park K, Tan E-H, O'Byrne K, Zhang L, Boyer M, Mok T, et al. Afatinib versus gefitinib as first-line treatment of patients with EGFR mutation-positive non-small-cell lung cancer (LUX-Lung 7): a phase 2B, open-label, randomised controlled trial. Lancet Oncol. 2016;17(5):577-89.

62. Ramalingam SS, Vansteenkiste J, Planchard D, Cho BC, Gray JE, Ohe $Y$, et al. Overall survival with osimertinib in untreated, EGFR-mutated advanced NSCLC. N Engl J Med. 2020;382(1):41-50.

63. Papadimitrakopoulou V, MokT, Han J-Y, Ahn M-J, Delmonte A, Ramalingam $\mathrm{S}$, et al. Osimertinib versus platinum-pemetrexed for patients with EGFR T790M advanced NSCLC and progression on a prior EGFRtyrosine kinase inhibitor: AURA3 overall survival analysis. Ann Oncol. 2020;31(11):1536-44.

64. Jackman D, Pao W, Riely GJ, Engelman JA, Kris MG, Jänne PA, et al. Clinical definition of acquired resistance to epidermal growth factor receptor tyrosine kinase inhibitors in non-small-cell lung cancer. J Clin Oncol. 2010;28(2):357-60.

65. Wu YL, Cheng Y, Zhou X, Lee KH, Nakagawa K, Niho S, et al. Dacomitinib versus gefitinib as first-line treatment for patients with EGFR-mutationpositive non-small-cell lung cancer (ARCHER 1050): a randomised, open-label, phase 3 trial. Lancet Oncol. 2017;18(11):1454-66.

66. Wu S-G, Shih J-Y. Management of acquired resistance to EGFRTKItargeted therapy in advanced non-small cell lung cancer. Mol Cancer. 2018;17(1):1-14

67. Kobayashi S, Boggon TJ, Dayaram T, Jänne PA, Kocher O, Meyerson M, et al. EGFR mutation and resistance of non-small-cell lung cancer to gefitinib. N Engl J Med. 2005;352(8):786-92.

68. Wu S-G, Liu Y-N, Tsai M-F, Chang Y-L, Yu C-J, Yang P-C, et al. The mechanism of acquired resistance to irreversible EGFR tyrosine kinase inhibitor-afatinib in lung adenocarcinoma patients. Oncotarget. 2016;7(11):12404.

69. Yun C-H, Mengwasser KE, Toms AV, Woo MS, Greulich H, Wong K-K, et al. The T790M mutation in EGFR kinase causes drug resistance by increasing the affinity for ATP. Proc Natl Acad Sci U S A. 2008;105(6):2070-5.

70. Skrzypski M, Szymanowska-Narloch A, Dziadziuszko R. Osimertinibeffective treatment of NSCLC with activating EGFR mutations after progression on EGFR tyrosine kinase inhibitors. Contemp Oncol (Pozn). 2017;21(3):254.

71. Helena AY, Arcila ME, Rekhtman N, Sima CS, Zakowski MF, Pao W, et al. Analysis of tumor specimens at the time of acquired resistance to EGFRTKI therapy in 155 patients with EGFR-mutant lung cancers. Clin Cancer Res. 2013;19(8):2240-7.
72. Engelman JA, Zejnullahu K, Mitsudomi T, Song Y, Hyland C, Park JO, et al. MET amplification leads to gefitinib resistance in lung cancer by activating ERBB3 signaling. Science. 2007;316(5827):1039-43.

73. Bean J, Brennan C, Shih J-Y, Riely G, Viale A, Wang L, et al. MET amplification occurs with or without T790M mutations in EGFR mutant lung tumors with acquired resistance to gefitinib or erlotinib. Proc Natl Acad Sci U S A. 2007;104(52):20932-7.

74. Fan W, Tang Z, Yin L, Morrison B, Hafez-Khayyata S, Fu P, et al. METindependent lung cancer cells evading EGFR kinase inhibitors are therapeutically susceptible to $\mathrm{BH} 3$ mimetic agents. Cancer Res. 2011;71(13):4494-505.

75. Xu J, Wang J, Zhang S. Mechanisms of resistance to irreversible epidermal growth factor receptor tyrosine kinase inhibitors and therapeutic strategies in non-small cell lung cancer. Oncotarget. 2017;8(52):90557.

76. Jakobsen JN, Santoni-Rugiu E, Grauslund M, Melchior L, Sørensen JB. Concomitant driver mutations in advanced EGFR-mutated non-smallcell lung cancer and their impact on erlotinib treatment. Oncotarget. 2018;9(40):26195.

77. Takezawa K, Pirazzoli V, Arcila ME, Nebhan CA, Song X, de Stanchina E, et al. HER2 amplification: a potential mechanism of acquired resistance to EGFR inhibition in EGFR-mutant lung cancers that lack the secondsite EGFRT790M mutation. Cancer Discov. 2012;2(10):922-33.

78. Sequist LV, Waltman BA, Dias-Santagata D, Digumarthy S, Turke AB, Fidias $P$, et al. Genotypic and histological evolution of lung cancers acquiring resistance to EGFR inhibitors. Sci Transl Med. 2011;3(75):75ra26.

79. Zhang Z, Lee JC, Lin L, Olivas V, Au V, LaFramboise T, et al. Activation of the AXL kinase causes resistance to EGFR-targeted therapy in lung cancer. Nat Genet. 2012;44(8):852-60.

80. Oser MG, Niederst MJ, Sequist LV, Engelman JA. Transformation from non-small-cell lung cancer to small-cell lung cancer: molecular drivers and cells of origin. Lancet Oncol. 2015;16(4):e165-e72.

81. Ali G, Bruno R, Giordano M, Prediletto I, Marconi L, Zupo S, et al. Small cell lung cancer transformation and the T790M mutation: a case report of two acquired mechanisms of TKI resistance detected in a tumor rebiopsy and plasma sample of EGFR-mutant lung adenocarcinoma. Oncol Lett. 2016;12(5):4009-12.

82. Sonoda T, Nishikawa S, Sakakibara R, Saiki M, Ariyasu R, Koyama J, et al. EGFR T790M mutation after chemotherapy for small cell lung cancer transformation of EGFR-positive non-small cell lung cancer. Respir Med Case Rep. 2018;24:19-21.

83. Thiery JP, Acloque H, Huang RY, Nieto MA. Epithelial-mesenchymal transitions in development and disease. Cell. 2009;139(5):871-90.

84. Chang T-H, Tsai M-F, Su K-Y, Wu S-G, Huang C-P, Yu S-L, et al. Slug confers resistance to the epidermal growth factor receptor tyrosine kinase inhibitor. Am J Respir Crit Care Med. 2011;183(8):1071-9.

85. Liam CK, Mallawathantri S, Fong KM. Is tissue still the issue in detecting molecular alterations in lung cancer? Respirology. 2020;25(9):933-43.

86. Wang L, Balasubramanian P, Chen AP, Kummar S, Evrard YA, Kinders RJ. Promise and limits of the CellSearch platform for evaluating pharmacodynamics in circulating tumor cells. Semin Oncol. 2016;43(4):464-75.

87. Ramsköld D, Luo S, Wang Y-C, Li R, Deng Q, Faridani OR, et al. Full-length mRNA-Seq from single-cell levels of RNA and individual circulating tumor cells. Nat Biotechnol. 2012:30(8):777-82.

88. Vu-Dinh $H$, Feng $H$, Jen C-P. Effective isolation for Lung carcinoma cells based on Immunomagnetic separation in a Microfluidic Channel. Biosensors (Basel). 2021;11(1):23.

89. Svobodova Z, Kucerova J, Autebert J, Horak D, Bruckova L, Viovy JL, et al. Application of an improved magnetic immunosorbent in an Ephesia chip designed for circulating tumor cell capture. Electrophoresis. 2014;35(2-3):323-9.

90. Krebs MG, Hou J-M, Sloane R, Lancashire L, Priest L, Nonaka D, et al. Analysis of circulating tumor cells in patients with non-small cell lung cancer using epithelial marker-dependent and-independent approaches. J Thorac Oncol. 2012;7(2):306-15.

91. Tong B, Xu Y, Zhao J, Chen M, Xing J, Zhong W, et al. Prognostic significance of circulating tumor cells in non-small cell lung cancer patients undergoing chemotherapy. Oncotarget. 2017;8(49):86615.

92. Sollier E, Go DE, Che J, Gossett DR, O'Byrne S, Weaver WM, et al. Sizeselective collection of circulating tumor cells using Vortex technology. Lab Chip. 2014;14(1):63-77. 
93. Lei Y, Tang R, Xu J, Wang W, Zhang B, Liu J, et al. Applications of single-cell sequencing in cancer research: progress and perspectives. J Hematol Oncol. 2021;14(1):1-26.

94. van Dessel LF, Vitale SR, Helmijr JC, Wilting SM, van der Vlugt-Daane M, Oomen-de Hoop E, et al. High-throughput isolation of circulating tumor DNA: a comparison of automated platforms. Mol Oncol. 2019;13(2):392-402

95. Zheng Y-Y, Fei Y, Wang Z, Chen Y, Qiu C, Li F-R. Tissue microRNAs in nonsmall cell lung cancer detected with a new kind of liquid bead array detection system. J Transl Med. 2020;18(1):1-11.

96. Russo G, Zegar C, Giordano A. Advantages and limitations of microarray technology in human cancer. Oncogene. 2003;22(42):6497-507.

97. Giallombardo M, Borrás JC, Castiglia M, Van Der Steen N, Mertens I, Pauwels $\mathrm{P}$, et al. Exosomal miRNA analysis in non-small cell lung cancer (NSCLC) patients' plasma through qPCR: a feasible liquid biopsy tool. J Vis Exp. 2016;111:53900.

98. Li P, Kaslan M, Lee S, Yao J, Gao Z. Progress in exosome isolation techniques. Theranostics. 2017;7(3):789-804.

99. Batrakova EV, Kim MS. Using exosomes, naturally-equipped nanocarriers, for drug delivery. J Control Release. 2015;219:396-405.

100. Chiriacò MS, Bianco M, Nigro A, Primiceri E, Ferrara F, Romano A, et al. Lab-on-chip for exosomes and microvesicles detection and characterization. Sensors (Basel). 2018;18(10):3175.

101. Wurdinger T. Tumor-educated platelets. Blood. 2019;133(22):2359-64.

102. Roweth HG, Battinelli EM. Lessons to learn from tumor-educated platelets. Blood. 2021;137(23):3174-80.

103. Heitzer $E$, Auinger $L$, Speicher MR. Cell-free DNA and apoptosis: how dead cells inform about the living. Trends Mol Med. 2020;26(5):519-28.

104. Hu Z, Chen H, Long Y, Li P, Gu Y. The main sources of circulating cell-free DNA: apoptosis, necrosis and active secretion. Crit Rev Oncol Hematol. 2021:157:103166.

105. Franovic A, Raymond VM, Erlander MG, Reckamp KL. Urine test for EGFR analysis in patients with non-small cell lung cancer. J Thorac Dis. 2017;9(Suppl 13):S1323.

106. Ponti G, Manfredini M, Tomasi A. Non-blood sources of cell-free DNA for cancer molecular profiling in clinical pathology and oncology. Crit Rev Oncol Hematol. 2019;141:36-42.

107. Satapathy S, Singh V, Nambirajan A, Malik PS, Tanwar P, Mehta A, et al. EGFR mutation testing on plasma and urine samples: a pilot study evaluating the value of liquid biopsy in lung cancer diagnosis and management. Curr Probl Cancer. 2021;45:100722.

108. Li Y, Zhang F, Yuan $P$, Guo L, Jianming Y, He J. High MAF of EGFR mutations and high ratio of T790M sensitizing mutations in ctDNA predict better third-generation TKI outcomes. Thorac Cancer. 2020;11(6):1503-11.

109. Del Re M, Crucitta S, Gianfilippo G, Passaro A, Petrini I, Restante G, et al. Understanding the mechanisms of resistance in EGFR-positive NSCLC: from tissue to liquid biopsy to guide treatment strategy. Int J Mol Sci. 2019;20(16):3951.

110. Shen J, Todd NW, Zhang H, Yu L, Lingxiao X, Mei Y, et al. Plasma microRNAs as potential biomarkers for non-small-cell lung cancer. Lab Investig. 2011;91(4):579-87.

111. Sacher AG, Paweletz C, Dahlberg SE, Alden RS, O'Connell A, Feeney $\mathrm{N}$, et al. Prospective validation of rapid plasma genotyping for the detection of EGFR and KRAS mutations in advanced lung cancer. JAMA Oncol. 2016;2(8):1014-22.

112. Mao X, Liu C, Tong H, Chen Y, Liu K. Principles of digital PCR and its applications in current obstetrical and gynecological diseases. Am J Transl Res. 2019;11(12):7209.

113. Li F, Wei F, Huang W-L, Lin C-C, Li L, Shen MM, et al. Ultra-short circulating tumor DNA (usctDNA) in plasma and saliva of non-small cell Lung Cancer (NSCLC) patients. Cancers (Basel). 2020;12(8):2041.

114. Leighl NB, Page RD, Raymond VM, Daniel DB, Divers SG, Reckamp $\mathrm{KL}$, et al. Clinical utility of comprehensive cell-free DNA analysis to identify genomic biomarkers in patients with newly diagnosed metastatic non-small cell lung cancer. Clin Cancer Res 2019;25(15):4691-700.

115. Avanzini S, Kurtz DM, Chabon JJ, Moding EJ, Hori SS, Gambhir SS, et al A mathematical model of ctDNA shedding predicts tumor detection size. Sci Adv. 2020;6(50):eabc4308
116. Passiglia F, Rizzo S, Di Maio M, Galvano A, Badalamenti G, Listì A, et al. The diagnostic accuracy of circulating tumor DNA for the detection of EGFR-T790M mutation in NSCLC: a systematic review and meta-analysis. Sci Rep. 2018;8(1):1-10.

117. Jensen SG, Epistolio S, Madsen CL, Kyneb MH, Riva A, Paganotti A, et al. A new sensitive and fast assay for the detection of EGFR mutations in liquid biopsies. PLoS One. 2021;16(6):e0253687.

118. Nakano Y, Isobe K, Kobayashi H, Kaburaki K, Isshiki T, Sakamoto S, et al. Clinical importance of long non-coding RNA LINC00460 expression in EGFR-mutant lung adenocarcinoma. Int J Oncol. 2020;56(1):243-57.

119. Shu D, Xu Y, Chen W. Knockdown of IncRNA BLACAT1 reverses the resistance of afatinib to non-small cell lung cancer via modulating STAT3 signalling. J Drug Target. 2020;28(3):300-6.

120. Chen Y, Li C, Pan Y, Han S, Feng B, Gao Y, et al. The emerging role and promise of long noncoding RNAs in lung cancer treatment. Cell Physiol Biochem. 2016;38(6):2194-206.

121. Castellanos-Rizaldos E, Zhang X, Tadigotla VR, Grimm DG, Karlovich C, Raez LE, et al. Exosome-based detection of activating and resistance EGFR mutations from plasma of non-small cell lung cancer patients. Oncotarget. 2019:10(30):2911-20.

122. Krug A, Enderle D, Karlovich C, Priewasser T, Bentink S, Spiel A, et al. Improved EGFR mutation detection using combined exosomal RNA and circulating tumor DNA in NSCLC patient plasma. Ann Oncol. 2018:29(3):700-6.

123. Kim Y, Shin S, Kim B, Lee K-A. Selecting short length nucleic acids localized in exosomes improves plasma EGFR mutation detection in NSCLC patients. Cancer Cell Int. 2019;19(1):1-9.

124. Best MG, Sol N, GJG S, Vancura A, Muller M, Niemeijer AL, et al. Swarm intelligence-enhanced detection of non-small-cell lung cancer using tumor-educated platelets. Cancer Cell. 2017;32(2):238-52 e9.

125. Best MG, Sol N, Kooi I, Tannous J, Westerman BA, Rustenburg F, et al. RNA-Seq of tumor-educated platelets enables blood-based pan-cancer, multiclass, and molecular pathway cancer diagnostics. Cancer Cell. 2015;28(5):666-76.

126. Wu Y-L, Zhou C, Liam C-K, Wu G, Liu X, Zhong Z, et al. First-line erlotinib versus gemcitabine/cisplatin in patients with advanced EGFR mutationpositive non-small-cell lung cancer: analyses from the phase III, randomized, open-label, ENSURE study. Ann Oncol. 2015;26(9):1883-9.

127. Leonetti A, Sharma S, Minari R, Perego P, Giovannetti E, Tiseo M. Resistance mechanisms to osimertinib in EGFR-mutated non-small cell lung cancer. Br J Cancer. 2019;121(9):725-37.

128. Goss G, Tsai C-M, Shepherd FA, Bazhenova L, Lee JS, Chang G-C, et al. Osimertinib for pretreated EGFR Thr790Met-positive advanced nonsmall-cell lung cancer (AURA2): a multicentre, open-label, single-arm, phase 2 study. Lancet Oncol. 2016;17(12):1643-52.

129. Yang J, Ahn M, Kim D, Ramalingam S, Sequist L, Wc S, et al. Osimertinib in pretreated T790M-positive advanced non-small-cell lung cancer: AURA study phase II extension component. J Clin Oncol. 2017:35(12):1288-96.

130. Lee JY, Qing X, Xiumin W, Yali B, Chi S, Bak SH, et al. Longitudinal monitoring of EGFR mutations in plasma predicts outcomes of NSCLC patients treated with EGFR TKIs: Korean Lung Cancer consortium (KLCC12-02). Oncotarget. 2016;7(6):6984.

131. Hu Y, Alden RS, Odegaard JI, Fairclough SR, Chen R, Heng J, et al. Discrimination of germline EGFR T790M mutations in plasma cell-free DNA allows study of prevalence across 31,414 cancer patients. Clin Cancer Res. 2017;23(23):7351-9.

132. Kuang Y, Rogers A, Yeap BY, Wang L, Makrigiorgos M, Vetrand K, et al. Noninvasive detection of EGFR T790M in gefitinib or erlotinib resistant non-small cell lung cancer. Clin Cancer Res. 2009;15(8):2630-6.

133. Murtaza M, Dawson S-J, Tsui DW, Gale D, Forshew T, Piskorz AM, et al. Non-invasive analysis of acquired resistance to cancer therapy by sequencing of plasma DNA. Nature. 2013;497(7447):108-12.

134. Sakai K, Horiike A, Irwin DL, Kudo K, Fujita Y, Tanimoto A, et al. Detection of epidermal growth factor receptor T790M mutation in plasma DNA from patients refractory to epidermal growth factor receptor tyrosine kinase inhibitor. Cancer Sci. 2013;104(9):1198-204.

135. Wang Z, Chen R, Wang S, Zhong J, Wu M, Zhao J, et al. Quantification and dynamic monitoring of EGFR T790M in plasma cell-free DNA by digital PCR for prognosis of EGFR-TKI treatment in advanced NSCLC. PLoS One. 2014;9(11):e110780. 
136. Thress KS, Brant R, Carr TH, Dearden S, Jenkins S, Brown H, et al. EGFR mutation detection in ctDNA from NSCLC patient plasma: a crossplatform comparison of leading technologies to support the clinical development of AZD9291. Lung Cancer. 2015;90(3):509-15.

137. Sundaresan TK, Sequist LV, Heymach JV, Riely GJ, Jänne PA, Koch WH, et al. Detection of T790M, the acquired resistance EGFR mutation, by tumor biopsy versus noninvasive blood-based analyses. Clin Cancer Res. 2016;22(5):1103-10.

138. Sueoka-Aragane N, Katakami N, Satouchi M, Yokota S, Aoe K, I wanaga K, et al. Monitoring EGFR T790M with plasma DNA from lung cancer patients in a prospective observational study. Cancer Sci. 2016;107(2):162-7.

139. Yanagita M, Redig AJ, Paweletz CP, Dahlberg SE, O'Connell A, Feeney N, et al. A prospective evaluation of circulating tumor cells and cell-free DNA in EGFR-mutant non-small cell lung cancer patients treated with erlotinib on a phase II trial. Clin Cancer Res. 2016;22(24):6010-20.

140. Zheng D, Ye X, Zhang M, Sun Y, Wang J, Ni J, et al. Plasma EGFRT790M ctDNA status is associated with clinical outcome in advanced NSCLC patients with acquired EGFR-TKI resistance. Sci Rep. 2016;6(1):1-9.

141. Chabon JJ, Simmons AD, Lovejoy AF, Esfahani MS, Newman AM, Haringsma $\mathrm{HJ}$, et al. Circulating tumour DNA profiling reveals heterogeneity of EGFR inhibitor resistance mechanisms in lung cancer patients. Nat Commun. 2016;7(1):1-15.

142. Novello S, Barlesi F, Califano R, Cufer T, Ekman S, Levra MG, et al. Metastatic non-small-cell lung cancer: ESMO clinical practice guidelines for diagnosis, treatment and follow-up. Ann Oncol. 2016;27:v1-v27.

143. Rachiglio AM, Fenizia F, Piccirillo MC, Galetta D, Crinò L, Vincenzi B, et al. The presence of concomitant mutations affects the activity of EGFR tyrosine kinase inhibitors in EGFR-mutant non-small cell lung cancer (NSCLC) patients. Cancers. 2019;11(3):341.

144. Del Re M, Tiseo M, Bordi P, D'Incecco A, Camerini A, Petrini l, et al. Contribution of KRAS mutations and c. 2369C> T (p. T790M) EGFR to acquired resistance to EGFR-TKIs in EGFR mutant NSCLC: a study on circulating tumor DNA. Oncotarget. 2017;8(8):13611.

145. Tsui DWY, Murtaza M, Wong ASC, Rueda OM, Smith CG, Chandrananda $D$, et al. Dynamics of multiple resistance mechanisms in plasma DNA during EGFR-targeted therapies in non-small cell lung cancer. EMBO Mol Med. 2018;10(6):e7945.

146. Niederst MJ, Sequist LV, Poirier JT, Mermel CH, Lockerman EL, Garcia $A R$, et al. RB loss in resistant EGFR mutant lung adenocarcinomas that transform to small-cell lung cancer. Nat Commun. 2015;6(1):1-10.

147. ClinicalTrials.gov. Bethesda (MD): U.S. National Library of Medicine. https://clinicaltrials.gov/. Accessed 21 Sept 2021.

148. Rizvi NA, Hellmann MD, Snyder A, Kvistborg P, Makarov V, Havel JJ, et al. Mutational landscape determines sensitivity to PD-1 blockade in nonsmall cell lung cancer. Science. 2015;348(6230):124-8.

149. Gandara DR, Paul SM, Kowanetz M, Schleifman E, Zou W, Li Y, et al. Blood-based tumor mutational burden as a predictor of clinical benefit in non-small-cell lung cancer patients treated with atezolizumab. Nat Med. 2018;24(9):1441-8.

150. Hofman P. Next-generation sequencing with liquid biopsies from treatment-Naïve non-small cell Lung carcinoma patients. Cancers (Basel). 2021;13(9):2049.

151. Jamal-Hanjani M, Wilson GA, McGranahan N, Birkbak NJ, Watkins TB, Veeriah S, et al. Tracking the evolution of non-small-cell lung cancer. N Engl J Med. 2017;376(22):2109-21.

152. Blakely CM, Watkins TB, Wu W, Gini B, Chabon JJ, McCoach CE, et al. Evolution and clinical impact of co-occurring genetic alterations in advanced-stage EGFR-mutant lung cancers. Nat Genet. 2017:49(12):1693-704.

153. Mack PC, Banks KC, Espenschied CR, Burich RA, Zill OA, Lee CE, et al. Spectrum of driver mutations and clinical impact of circulating tumor DNA analysis in non-small cell lung cancer: analysis of over 8000 cases. Cancer. 2020;126(14):3219-28.

154. Oxnard GR, Thress KS, Alden RS, Lawrance R, Paweletz CP, Cantarini $M$, et al. Association between plasma genotyping and outcomes of treatment with osimertinib (AZD9291) in advanced non-small-cell lung cancer. J Clin Oncol. 2016;34(28):3375.

155. Gay C, Toulet D, Le Corre P. Pharmacokinetic drug-drug interactions of tyrosine kinase inhibitors: a focus on cytochrome P450, transporters, and acid suppression therapy. Hematol Oncol. 2017;35(3):259-80.
156. Dean M, Hamon Y, Chimini G. The human ATP-binding cassette (ABC) transporter superfamily. J Lipid Res. 2001;42(7):1007-17.

157. Leschziner G, Andrew T, Pirmohamed M, Johnson M. ABCB1 genotype and PGP expression, function and therapeutic drug response: a critical review and recommendations for future research. Pharmacogenomics J. 2007;7(3):154-79.

158. McKillop D, McCormick A, Millar A, Miles G, Phillips P, Hutchison M. Cytochrome P450-dependent metabolism of gefitinib. Xenobiotica. 2005:35(1):39-50

159. Swaisland HC, Cantarini MV, Fuhr R, Holt A. Exploring the relationship between expression of cytochrome P450 enzymes and gefitinib pharmacokinetics. Clin Pharmacokinet. 2006;45(6):633-44.

160. Kitazaki T, Oka M, Nakamura Y, Tsurutani J, Doi S, Yasunaga M, et al. Gefitinib, an EGFR tyrosine kinase inhibitor, directly inhibits the function of P-glycoprotein in multidrug resistant cancer cells. Lung Cancer. 2005:49(3):337-43.

161. Yang C-H, Huang C-J, Yang C-S, Chu Y-C, Cheng A-L, Whang-Peng J, et al. Gefitinib reverses chemotherapy resistance in gefitinib-insensitive multidrug resistant cancer cells expressing ATP-binding cassette family protein. Cancer Res. 2005;65(15):6943-9.

162. Semba Y, Akiyoshi T, Hibino H, Imaoka A, Ohtani H. Profile of the inhibitory effects of gefitinib on CYP2D6 variants in vitro. Int J Clin Pharmacol Ther. 2020;58(10):539.

163. Li J, Zhao M, He P, Hidalgo M, Baker SD. Differential metabolism of gefitinib and erlotinib by human cytochrome P450 enzymes. Clin Cancer Res. 2007;13(12):3731-7.

164. Alfieri RR, Galetti M, Tramonti S, Andreoli R, Mozzoni P, Cavazzoni A, et al. Metabolism of the EGFR tyrosin kinase inhibitor gefitinib by cytochrome P450 1A1 enzyme in EGFR-wild type non small cell lung cancer cell lines. Mol Cancer. 2011;10(1):1-14.

165. Vlaming ML, Läppchen $T$, Jansen $H T$, Kivits $S$, van Driel $A$, van de Steeg E, et al. PET-CT imaging with [18F]-gefitinib to measure Abcb1a/1b (P-gp) and Abcg2 (Bcrp1) mediated drug-drug interactions at the murine blood-brain barrier. Nucl Med Biol. 2015;42(11):833-41.

166. Agarwal S, Sane R, Gallardo JL, Ohlfest JR, Elmquist WF. Distribution of gefitinib to the brain is limited by P-glycoprotein (ABCB1) and breast cancer resistance protein (ABCG2)-mediated active efflux. J Pharmacol Exp Ther. 2010;334(1):147-55.

167. Wan Z, Guo L, Li P, Zhao Z, Xu B, Ren L, et al. Determinants of gefitinib pharmacokinetics in healthy Chinese male subjects: a pharmacogenomic study of cytochrome p450 enzymes and transporters. J Clin Pharm Ther. 2020;45(5):1159-67.

168. Svedberg A, Vikingsson S, Vikström A, Hornstra N, Kentson M, Branden E, et al. Erlotinib treatment induces cytochrome P450 $3 \mathrm{~A}$ activity in nonsmall cell lung cancer patients. Br J Clin Pharmacol. 2019;85(8):1704-9.

169. White-Koning M, Civade E, Geoerger B, Thomas F, Le Deley M-C, Hennebelle I, et al. Population analysis of erlotinib in adults and children reveals pharmacokinetic characteristics as the main factor explaining tolerance particularities in children. Clin Cancer Res. 2011;17(14):4862-71.

170. Wind S, Schnell D, Ebner T, Freiwald M, Stopfer P. Clinical pharmacokinetics and pharmacodynamics of afatinib. Clin Pharmacokinet. 2017:56(3):235-50.

171. Stopfer P, Marzin K, Narjes H, Gansser D, Shahidi M, Uttereuther-Fischer $M$, et al. Afatinib pharmacokinetics and metabolism after oral administration to healthy male volunteers. Cancer Chemother Pharmacol. 2012;69(4):1051-61.

172. Zhang Y, Wang C, Liu Z, Meng Q, Huo X, Liu Q, et al. P-gp is involved in the intestinal absorption and biliary excretion of afatinib in vitro and in rats. Pharmacol Rep. 2018;70(2):243-50.

173. van Hoppe S, Sparidans RW, Wagenaar E, Beijnen JH, Schinkel AH. Breast cancer resistance protein (BCRP/ABCG2) and P-glycoprotein (P-gp/ABCB1) transport afatinib and restrict its oral availability and brain accumulation. Pharmacol Res. 2017;120:43-50.

174. Bello CL, LaBadie RR, Ni G, Boutros T, McCormick C, Ndongo MN. The effect of dacomitinib (PF-00299804) on CYP2D6 activity in healthy volunteers who are extensive or intermediate metabolizers. Cancer Chemother Pharmacol. 2012;69(4):991-7.

175. Peters S, Zimmermann S, Adjei AA. Oral epidermal growth factor receptor tyrosine kinase inhibitors for the treatment of non-small cell lung 
cancer: comparative pharmacokinetics and drug-drug interactions. Cancer Treat Rev. 2014;40(8):917-26.

176. Dickinson PA, Cantarini MV, Collier J, Frewer P, Martin S, Pickup K, et al. Metabolic disposition of osimertinib in rats, dogs, and humans: insights into a drug designed to bind covalently to a cysteine residue of epidermal growth factor receptor. Drug Metab Dispos. 2016;44(8):1201-12.

177. van Hoppe S, Jamalpoor A, Rood JJ, Wagenaar E, Sparidans RW, Beijnen $\mathrm{JH}$, et al. Brain accumulation of osimertinib and its active metabolite AZ5104 is restricted by ABCB1 (P-glycoprotein) and ABCG2 (breast cancer resistance protein). Pharmacol Res. 2019;146:104297.

178. Zhang S, Jin S, Griffin C, Feng Z, Lin J, Venkatakrishnan K, et al. Effects of Itraconazole and rifampin on the pharmacokinetics of Mobocertinib (TAK-788), an Oral epidermal growth factor receptor inhibitor, in Healthy Volunteers. Clin Pharmacol Drug Dev. 2021;10(9):1044-53.

179. Huddart R, Fohner AE, Whirl-Carrillo M, Wojcik GL, Gignoux CR, Popejoy $A B$, et al. Standardized biogeographic grouping system for annotating populations in pharmacogenetic research. Clin Pharmacol Ther. 2019:105(5):1256-62.

180. Caudle KE, Dunnenberger HM, Freimuth RR, Peterson JF, Burlison JD, Whirl-Carrillo M, et al. Standardizing terms for clinical pharmacogenetic test results: consensus terms from the clinical Pharmacogenetics implementation consortium (CPIC). Genet Med. 2017;19(2):215-23.

181. Zhang F, Finkelstein J. Inconsistency in race and ethnic classification in pharmacogenetics studies and its potential clinical implications. Pharmgenomics Pers Med. 2019;12:107-23.

182. Ingelman-Sundberg M, Sim SC, Gomez A, Rodriguez-Antona C. Influence of cytochrome $\mathrm{P} 450$ polymorphisms on drug therapies: pharmacogenetic, pharmacoepigenetic and clinical aspects. Pharmacol Ther. 2007;116(3):496-526.

183. Caudle KE, Sangkuhl K, Whirl-Carrillo M, Swen JJ, Haidar CE, Klein TE, et al. Standardizing CYP 2D6 genotype to phenotype translation: consensus recommendations from the clinical Pharmacogenetics implementation consortium and Dutch Pharmacogenetics working group. Clin TransI Sci. 2020;13(1):116-24.

184. Swen J, Nijenhuis M, de Boer A, Grandia L, Maitland-van der Zee A-H, Mulder $\mathrm{H}$, et al. Pharmacogenetics: from bench to byte-an update of guidelines. Clin Pharmacol Ther. 2011;89(5):662-73.

185. Ingelman-Sundberg M. Genetic polymorphisms of cytochrome P 450 2D6 (CYP2D6): clinical consequences, evolutionary aspects and functional diversity. Pharmacogenomics J. 2005;5(1):6-13.

186. Fukushima-Uesaka H, Saito Y, Watanabe H, Shiseki K, Saeki M, Nakamura T, et al. Haplotypes of CYP3A4 and their close linkage with CYP3A5 haplotypes in a Japanese population. Hum Mutat. 2004;23(1):100.

187. Floyd MD, Gervasini G, Masica AL, Mayo G, George AL Jr, Bhat K, et al. Genotype-phenotype associations for common CYP3A4 and CYP3A5 variants in the basal and induced metabolism of midazolam in European-and African-American men and women. Pharmacogenetics. 2003;13(10):595-606.

188. Koonrungsesomboon N, Khatsri R, Wongchompoo P, Teekachunhatean S. The impact of genetic polymorphisms on CYP1A2 activity in humans: a systematic review and meta-analysis. Pharmacogenomics $J$. 2018;18(6):760-8.

189. Iwanari M, Nakajima M, Kizu R, Hayakawa K, Yokoi T. Induction of CYP1A1, CYP1A2, and CYP1B1 mRNAs by nitropolycyclic aromatic hydrocarbons in various human tissue-derived cells: chemical-, cytochrome P450 isoform-, and cell-specific differences. Arch Toxicol. 2002;76(5-6):287-98.

190. O'Malley M, King AN, Conte M, Ellingrod VL, Ramnath N. Effects of cigarette smoking on metabolism and effectiveness of systemic therapy for lung cancer. J Thorac Oncol. 2014;9(7):917-26.

191. Shimada T, Inoue K, Suzuki Y, Kawai T, Azuma E, Nakajima T, et al. Arylhydrocarbon receptor-dependent induction of liver and lung cytochromes P450 1A1, 1A2, and 1B1 by polycyclic aromatic hydrocarbons and polychlorinated biphenyls in genetically engineered C57BL/6J mice. Carcinogenesis. 2002;23(7):1199-207.

192. Quattrochi L, Vu T, Tukey R. The human CYP1A2 gene and induction by 3-methylcholanthrene. A region of DNA that supports AH-receptor binding and promoter-specific induction. J Biol Chem. 1994;269(9):6949-54.

193. Marwick JA, Kirkham PA, Stevenson CS, Danahay H, Giddings J, Butler $\mathrm{K}$, et al. Cigarette smoke alters chromatin remodeling and induces proinflammatory genes in rat lungs. Am J Respir Cell Mol Biol. 2004;31(6):633-42.

194. Ito K, Lim S, Caramori G, Chung K, Barnes P, Adcock I. Cigarette smoking reduces histone deacetylase 2 expression, enhances cytokine expression, and inhibits glucocorticoid actions in alveolar macrophages. FASEB J. 2001;15(6):1110-2.

195. Cardoso E, Guidi M, Khoudour N, Boudou-Rouquette P, Fabre E, Tlemsani C, et al. Population pharmacokinetics of Erlotinib in patients with non-small cell Lung Cancer: its application for individualized dosing regimens in older patients. Clin Ther. 2020;42(7):1302-16.

196. Clark GM. Prognostic factors versus predictive factors: examples from a clinical trial of erlotinib. Mol Oncol. 2008;1 (4):406-12.

197. Markóczy Z, Sárosi V, Kudaba I, Gálffy G, Turay ÜY, Demirkazik A, et al. Erlotinib as single agent first line treatment in locally advanced or metastatic activating EGFR mutation-positive lung adenocarcinoma (CEETAC): an open-label, non-randomized, multicenter, phase IV clinical trial. BMC Cancer. 2018;18(1):1-7.

198. Lu JF, Eppler SM, Wolf J, Hamilton M, Rakhit A, Bruno R, et al. Clinical pharmacokinetics of erlotinib in patients with solid tumors and exposure-safety relationship in patients with non-small cell lung cancer. Clin Pharmacol Ther. 2006;80(2):136-45.

199. Hughes AN, O'Brien ME, Petty WJ, Chick JB, Rankin E, Woll PJ, et al. Overcoming CYP1A1/1A2 mediated induction of metabolism by escalating erlotinib dose in current smokers. J Clin Oncol. 2009;27(8):1220.

200. Dobrinas M, Cornuz J, Eap CB. Pharmacogenetics of CYP1A2 activity and inducibility in smokers and exsmokers. Pharmacogenet Genomics. 2013;23(5):286-92.

201. Ghotbi R, Christensen M, Roh H-K, Ingelman-Sundberg M, Aklillu E, Bertilsson L. Comparisons of CYP1A2 genetic polymorphisms, enzyme activity and the genotype-phenotype relationship in swedes and Koreans. Eur J Clin Pharmacol. 2007:63(6):537-46.

202. Dobrinas M, Cornuz J, Oneda B, Kohler Serra M, Puhl M, Eap C. Impact of smoking, smoking cessation, and genetic polymorphisms on CYP1A2 activity and inducibility. Clin Pharmacol Ther. 2011;90(1):117-25.

203. Dobrinas M, Cornuz J, Pedrido L, Eap CB. Influence of cytochrome P450 oxidoreductase genetic polymorphisms on CYP1A2 activity and inducibility by smoking. Pharmacogenet Genomics. 2012;22(2):143-51.

204. Yoshinari K, Yoda N, Toriyabe T, Yamazoe Y. Constitutive androstane receptor transcriptionally activates human CYP1A1 and CYP1A2 genes through a common regulatory element in the 5 '-flanking region. Biochem Pharmacol. 2010;79(2):261-9.

205. Ghotbi R, Gomez A, Milani L, Tybring G, Syvänen A-C, Bertilsson L, et al. Allele-specific expression and gene methylation in the control of CYP1A2 mRNA level in human livers. Pharmacogenomics J. 2009;9(3):208-17.

206. Choi H-G, Jeon J-Y, Im Y-J, Kim Y, Song E-K, Seo Y-H, et al. Pharmacokinetic properties of two erlotinib $150 \mathrm{mg}$ formulations with a genetic effect evaluation in healthy Korean subjects. Clin Drug Investig. 2015;35(1):31-43

207. Parra-Guillen ZP, Berger PB, Haschke M, Donzelli M, Winogradova D, Pfister $B$, et al. Role of cytochrome P450 3A4 and 1A2 phenotyping in patients with advanced non-small-cell lung cancer receiving erlotinib treatment. Basic Clin Pharmacol Toxicol. 2017;121(4):309-15.

208. Kobayashi H, Sato K, Niioka T, Miura H, Ito H, Miura M. Relationship among gefitinib exposure, polymorphisms of its metabolizing enzymes and transporters, and side effects in Japanese patients with non-smallcell lung cancer. Clin Lung Cancer. 2015;16(4):274-81.

209. Kobayashi H, Sato K, Niioka T, Takeda M, Okuda Y, Asano M, et al. Effects of polymorphisms in CYP2D6 and ABC transporters and side effects induced by gefitinib on the pharmacokinetics of the gefitinib metabolite, O-desmethyl gefitinib. Med Oncol. 2016;33(6):57.

210. Suzumura T, Kimura T, Kudoh S, Umekawa K, Nagata M, Matsuura K, et al. Reduced CYP2D6 function is associated with gefitinib-induced rash in patients with non-small cell lung cancer. BMC Cancer. 2012;12(1):1-9.

211. Hoshitsuki K, Crews KR, Yang W, Smith CA, Hankins JS, Turner AJ, et al. Challenges in clinical implementation of CYP2D6 genotyping: choice of variants to test affects phenotype determination. Genet Med. 2020;22(1):232-3 
212. Chen X, Jiang J, Giri N, Hu P. Phase 1 study to investigate the pharmacokinetic properties of dacomitinib in healthy adult Chinese subjects genotyped for CYP2D6. Xenobiotica. 2018;48(5):459-66.

213. Sakamoto S, Sato K, Takita Y, Izumiya Y, Kumagai N, Sudo K, et al. ABCG2 C421A polymorphisms affect exposure of the epidermal growth factor receptor inhibitor gefitinib. Investig New Drugs. 2020;38(6):1687-95.

214. Xu Z-Y, Li J-L. Comparative review of drug-drug interactions with epidermal growth factor receptor tyrosine kinase inhibitors for the treatment of non-small-cell lung cancer. Onco Targets Ther. 2019;12:5467.

215. Hamada A, Sasaki J-i, Saeki S, Iwamoto N, Inaba M, Ushijima S, et al. Association of $A B C B 1$ polymorphisms with erlotinib pharmacokinetics and toxicity in Japanese patients with non-small-cell lung cancer. Pharmacogenomics. 2012;13(5):615-24.

216. Endo-Tsukude C, Sasaki J-i, Saeki S, Iwamoto N, Inaba M, Ushijima S, et al. Population pharmacokinetics and adverse events of erlotinib in Japanese patients with non-small-cell lung cancer: impact of genetic polymorphisms in metabolizing enzymes and transporters. Biol Pharm Bull. 2018;41(1):47-56.

217. Fukudo M, Ikemi Y, Togashi Y, Masago K, Kim YH, Mio T, et al. Population pharmacokinetics/pharmacodynamics of erlotinib and pharmacogenomic analysis of plasma and cerebrospinal fluid drug concentrations in Japanese patients with non-small cell lung cancer. Clin Pharmacokinet. 2013;52(7):593-609.

218. Akasaka K, Kaburagi T, Si Y, Ohmori K, Abe K, Sagara H, et al. Impact of functional ABCG2 polymorphisms on the adverse effects of gefitinib in Japanese patients with non-small-cell lung cancer. Cancer Chemother Pharmacol. 2010;66(4):691-8.

219. Elmeliegy MA, Carcaboso AM, Tagen M, Bai F, Stewart CF. Role of ATP-binding cassette and solute carrier transporters in erlotinib CNS penetration and intracellular accumulation. Clin Cancer Res. 2011:17(1):89-99.

220. Kodaira H, Kusuhara H, Ushiki J, Fuse E, Sugiyama Y. Kinetic analysis of the cooperation of P-glycoprotein (P-gp/Abcb1) and breast cancer resistance protein (Bcrp/Abcg2) in limiting the brain and testis penetration of erlotinib, flavopiridol, and mitoxantrone. J Pharmacol Exp Ther. 2010;333(3):788-96

221. de Vries NA, Buckle T, Zhao J, Beijnen JH, Schellens JH, van Tellingen O. Restricted brain penetration of the tyrosine kinase inhibitor erlotinib due to the drug transporters P-gp and BCRP. Investig New Drugs. 2012;30(2):443-9.

222. Zhao M, He P, Rudek MA, Hidalgo M, Baker SD. Specific method for determination of OSI-774 and its metabolite OSI-420 in human plasma by using liquid chromatography-tandem mass spectrometry. J Chromatogr B Anal Technol Biomed Life Sci. 2003;793(2):413-20.

223. Masters AR, Sweeney CJ, Jones DR. The quantification of erlotinib (OSI774) and OSI-420 in human plasma by liquid chromatography-tandem mass spectrometry. J Chromatogr B Anal Technol Biomed Life Sci. 2007;848(2):379-83.

224. Lepper ER, Swain SM, Tan AR, Figg WD, Sparreboom A. Liquid-chromatographic determination of erlotinib (OSI-774), an epidermal growth factor receptor tyrosine kinase inhibitor. J Chromatogr B Anal Technol Biomed Life Sci. 2003;796(1):181-8.

225. Bouchet S, Chauzit E, Ducint D, Castaing N, Canal-Raffin M, Moore N, et al. Simultaneous determination of nine tyrosine kinase inhibitors by 96-well solid-phase extraction and ultra performance LC/MS-MS. Clin Chim Acta. 2011;412(11-12):1060-7.

226. Jones HK, Stafford L, Swaisland H, Payne R. A sensitive assay for ZD1839 (Iressa) in human plasma by liquid-liquid extraction and high performance liquid chromatography with mass spectrometric detection: validation and use in phase I clinical trials. J Pharm Biomed Anal. 2002;29(1-2):221-8.

227. Guetens G, Prenen H, De Boeck G, Van Dongen W, Esmans E, Lemiere $F$, et al. Sensitive and specific quantification of the anticancer agent ZD1839 (Gefitinib) in plasma by on-column focusing capillary liquid chromatography-tandem mass spectrometry. J Chromatogr A. 2005;1082(1):2-5.

228. Chahbouni A, Den Burger J, Vos R, Sinjewel A, Wilhelm A. Simultaneous quantification of erlotinib, gefitinib, and imatinib in human plasma by liquid chromatography tandem mass spectrometry. Ther Drug Monit. 2009:31(6):683-7.
229. Wang L-Z, Lim MY-X, Chin T-M, Thuya W-L, Nye P-L, Wong A, et al. Rapid determination of gefitinib and its main metabolite, O-desmethyl gefitinib in human plasma using liquid chromatography-tandem mass spectrometry. J Chromatogr B Anal Technol Biomed Life Sci. 2011;879(22):2155-61.

230. Rood JJ, van Bussel MT, Schellens JH, Beijnen JH, Sparidans RW. Liquid chromatography-tandem mass spectrometric assay for the T790M mutant EGFR inhibitor osimertinib (AZD9291) in human plasma. J Chromatogr B Anal Technol Biomed Life Sci. 2016;1031:80-5.

231. Zheng X, Wang W, Zhang Y, Ma Y, Zhao H, Hu P, et al. Development and validation of a UPLC-MS/MS method for quantification of osimertinib (AZD9291) and its metabolite AZ5104 in human plasma. Biomed Chromatogr. 2018;32(12):e4365.

232. Arteaga CL, Baselga J. Clinical trial design and end points for epidermal growth factor receptor-targeted therapies: implications for drug development and practice. Clin Cancer Res. 2003;9(5):1579-89.

233. Freeman DJ, McDorman K, Ogbagabriel S, Kozlosky C, Yang B-B Doshi $\mathrm{S}$, et al. Tumor penetration and epidermal growth factor receptor saturation by panitumumab correlate with antitumor activity in a preclinical model of human cancer. Mol Cancer. 2012;11(1):1-11.

234. Baselga J, Pfister D, Cooper M, Cohen R, Burtness B, Bos M, et al. Phase I studies of anti-epidermal growth factor receptor chimeric antibody C225 alone and in combination with cisplatin. J Clin Oncol. 2000;18(4):904-14.

235. Shin DM, Donato NJ, Perez-Soler R, Shin HJC, Wu JY, Zhang P, et al. Epidermal growth factor receptor-targeted therapy with C225 and cisplatin in patients with head and neck cancer. Clin Cancer Res. 2001;7(5):1204-13.

236. Albanell J, Rojo F, Averbuch S, Feyereislova A, Mascaro JM, Herbst $R$, et al. Pharmacodynamic studies of the epidermal growth factor receptor inhibitor ZD1839 in skin from cancer patients: histopathologic and molecular consequences of receptor inhibition. J Clin Oncol. 2002;20(1):110-24.

237. Wiley HS, Herbst JJ, Walsh BJ, Lauffenburger D, Rosenfeld M, Gill G. The role of tyrosine kinase activity in endocytosis, compartmentation, and down-regulation of the epidermal growth factor receptor. J Biol Chem. 1991;266(17):11083-94.

238. Burke PM, Wiley HS. Human mammary epithelial cells rapidly exchange empty EGFR between surface and intracellular pools. J Cell Physiol. 1999;180(3):448-60.

239. Liu F, Yuan X, Jiang J, Chu Q. Immunotherapy in advanced nonsmall-cell lung cancer with EGFR mutations. Immunotherapy. 2020;12(16):1195-207.

240. Ferri N, Bellosta S, Baldessin L, Boccia D, Racagni G, Corsini A. Pharmacokinetics interactions of monoclonal antibodies. Pharmacol Res. 2016:111:592-9.

241. Agustoni F, Suda K, Yu H, Ren S, Rivard CJ, Ellison K, et al. EGFRdirected monoclonal antibodies in combination with chemotherapy for treatment of non-small-cell lung cancer: an updated review of clinical trials and new perspectives in biomarkers analysis. Cancer Treat Rev. 2019;72:15-27.

242. Goldberg SB, Redman MW, Lilenbaum R, Politi K, Stinchcombe TE, Horn L, et al. Randomized trial of Afatinib plus Cetuximab versus Afatinib alone for first-line treatment of EGFR-mutant non-smallcell Lung Cancer: final results from SWOG S1403. J Clin Oncol. 2020;38(34):4076-85

243. Brahmer J, Reckamp KL, Baas P, Crinò L, Eberhardt WE, Poddubskaya E, et al. Nivolumab versus docetaxel in advanced squamous-cell nonsmall-cell lung cancer. N Engl J Med. 2015;373(2):123-35.

244. Gandhi L, Rodríguez-Abreu D, Gadgeel S, Esteban E, Felip E, De Angelis F, et al. Pembrolizumab plus chemotherapy in metastatic non-smallcell lung cancer. N Engl J Med. 2018;378(22):2078-92.

245. Hastings K, Yu H, Wei W, Sanchez-Vega F, DeVeaux M, Choi J, et al. EGFR mutation subtypes and response to immune checkpoint blockade treatment in non-small-cell lung cancer. Ann Oncol. 2019;30(8):1311-20

246. To KK, Fong W, Cho WC. Immunotherapy in treating EGFR-mutant Lung Cancer: current challenges and new strategies. Front Oncol. 2021;11:635007. 
247. Jin R, Zhao J, Xia L, Li Q, Li W, Peng L, et al. Application of immune checkpoint inhibitors in EGFR-mutant non-small-cell lung cancer: from bed to bench. Ther Adv Med Oncol. 2020;12:1758835920930333.

248. Harrison PT, Vyse S, Huang PH. Rare epidermal growth factor receptor (EGFR) mutations in non-small cell lung cancer. Semin Cancer Biol. 2020;61:167-79.

249. Nguyen H-N, Cao N-PT, Van Nguyen T-C, Le KND, Nguyen DT, Nguyen $\mathrm{Q}-\mathrm{TT}$, et al. Liquid biopsy uncovers distinct patterns of DNA methylation and copy number changes in NSCLC patients with different EGFR-TKI resistant mutations. Sci Rep. 2021;11(1):1-12.

250. Qin A, Ramnath N. The "liquid biopsy" in non-small cell lung cancer-not quite ready for prime time use. Transl Cancer Res. 2016;5(Suppl 4):S632.

251. Bettegowda C, Sausen M, Leary RJ, Kinde I, Wang Y, Agrawal N, et al. Detection of circulating tumor DNA in early-and late-stage human malignancies. Sci Transl Med. 2014;6(224):224ra24.

252. Offin M, Rizvi H, Tenet M, Ni A, Sanchez-Vega F, Li BT, et al. Tumor mutation burden and efficacy of EGFR-tyrosine kinase inhibitors in patients with EGFR-mutant lung cancers. Clin Cancer Res. 2019;25(3):1063-9.

253. Huang W-L, Chen Y-L, Yang S-C, Ho C-L, Wei F, Wong DT, et al. Liquid biopsy genotyping in lung cancer: ready for clinical utility? Oncotarget. 2017:8(11):18590.

254. Shekhani R, Steinacher L, Swen JJ, Ingelman-Sundberg M. Evaluation of current regulation and guidelines of pharmacogenomic drug labels: opportunities for improvements. Clin Pharmacol Ther 2020;107(5):1240-55.

255. Hlaváč V, Holý P, Souček P. Pharmacogenomics to predict tumor therapy response: a focus on ATP-binding cassette transporters and cytochromes P450. J Pers Med. 2020;10(3):108.

256. Shah RR, Gaedigk A. Precision medicine: does ethnicity information complement genotype-based prescribing decisions? Ther Adv Drug Saf. 2018:9(1):45-62.

257. Ahmed S, Zhou Z, Zhou J, Chen S-Q. Pharmacogenomics of drug metabolizing enzymes and transporters: relevance to precision medicine. Genomics Proteomics Bioinformatics. 2016;14(5):298-313.

\section{Publisher's Note}

Springer Nature remains neutral with regard to jurisdictional claims in published maps and institutional affiliations.

Ready to submit your research? Choose BMC and benefit from:

- fast, convenient online submission

- thorough peer review by experienced researchers in your field

- rapid publication on acceptance

- support for research data, including large and complex data types

- gold Open Access which fosters wider collaboration and increased citations

- maximum visibility for your research: over $100 \mathrm{M}$ website views per year

At $\mathrm{BMC}$, research is always in progress.

Learn more biomedcentral.com/submissions 